\title{
ANTIFUNGAL DISINFECTANTS EFFICIENCY ON ASPERGILLUS STRAINS FROM CAMEL'S MILK AND DRINKING WATER: BIOLOGICAL DETOXIFICATION OF AFLATOXIN-M1
}

\author{
HASSAN MAHMOUD DIAB ${ }^{1}$; AHMED SHABAN AHMED ${ }^{2}$; \\ LUAY ALKAZMI ${ }^{3}$; GABER EL-SABER BATIHA ${ }^{4}$ and MONA A. EL-ZAMKAN ${ }^{2}$ \\ ${ }^{1}$ Department of Animal and Poultry Health and Environment, Faculty of Veterinary \\ Medicine, South Valley University, Qena 83523, Egypt. \\ ${ }^{2}$ Department of Food Hygiene and Control (Milk Hygiene), Faculty of Veterinary \\ Medicine, South Valley University, Qena 83523, Egypt. \\ ${ }^{3}$ Biology Department, Faculty of Applied Sciences, Umm Al-Qura University, \\ Makkah 21955, Saudi Arabia. \\ ${ }^{4}$ Department of Pharmacology and Therapeutics, Faculty of Veterinary Medicine, \\ Damanhour University, Damanhour 22511, AlBeheira, Egypt.
}

Received: 3 October 2021; Accepted: 30 October 2021

\begin{abstract}
This study was conducted to assess the distribution of mold and mycotoxins in raw camel's milk and water samples and to evaluate the fungicidal activity of three disinfectants and the detoxification capabilities of LAB towards aflatoxin M1 in camel's milk. Molds were isolated from 56 and $64 \%$ of water and raw camel milk samples, respectively. Aspergillus spp. were the most abundant species isolated from water and raw camel milk samples with 10.9 and 11.6\%, respectively, followed by Penicillium and Fusarium spp. The concentrations of aflatoxin-B1 (AFB1) and ochratoxin-A (OTA) in the examined water samples were 7.97 and $8.28 \mu \mathrm{g} / \mathrm{l}$, respectively. Furthermore, the concentrations of aflatoxin-M1 (AFM1) and ochratoxin-A (OTA) in the examined raw camel milk samples were 1.89 and $1.69 \mu \mathrm{g} / \mathrm{l}$, respectively. Quaternary ammonium/glutaraldehyde based disinfectant was the most efficient disinfectants against the isolated fungal species. On contaminated dairy surfaces; exposure of A. flavus to Quaternary ammonium/glutaraldehyde based disinfectant for shorter contact times less than one-hour exhibited reduced efficacy with log reduction not exceed $2.6 \mathrm{log}$, while for A. ochraceus, a minimum of 15 minutes' exposure time was required to induce good efficacy with $3.2 \mathrm{log}$ reduction. Adjusting exposures time for one hour showed good efficacy for both A. flavus and A. ochraceus with 4.5 and $4.6 \mathrm{log}$ reduction, respectively. The AFM1 concentration in prepared yoghurt from camel's milk was reduced to $24.6 \%$ after the first 5 days of incubation; and after incubation for 15 and 20 days, further reduction to 45.9 and $55.7 \%$ was observed, respectively.
\end{abstract}

Key words: Camel milk, Water, Aspergillus, Mycotoxins, LAB, fingicidal activity, Disinfectant.

Abbreviations: AFB1, Aflatoxin B1; AFM1, Aflatoxin M1; aflD and aflQ, Aflatoxin B1 biosynthesis genes: the structural genes aflD and aflQ; OTA, Ochratoxin A; CFU, Colony forming unit; FE, Fungicidal Effect; HPLC, High Performance Liquid Chromatography; LAB, Lactic acid bacteria; MPL, Maximum permissible limits. 


\section{INTRODUCTION}

Camel's milk is packed with a variety of health nutritional elements, as well as possible anticarcinogenic, antihypertensive, and glycemic regulating properties and treatment of various infectious diseases (Solanki and Hati, 2018). As camel milk is of great economic and nutritional value, its safety is of special importance to farmers, producers and consumers. It is liable to be contaminated with mold at suitable conditions of temperature, moisture and storage under unhygienic conditions (Barrois et al., 1997). Molds can cause a variety of spoilage and the production of a wide range of metabolic by-products, resulting in off-flavor, change the color, and texture of food product and raise $\mathrm{pH}$ as well as visible growth of mold (Muir and Banks, 2000; ledenbach and marshall, 2010). As a result, mold and yeast counts are considered the industry benchmark for determining the shelf life and sanitary state of food (Foster et al., 1983).

Fungal contamination of food and water play a significant role in gastrointestinal troubles which negatively impact human health (Ahmed et al., 2020). In water distribution municipal networks and tap water, molds are a mutual member of the flora (Kelley et al., 1997; Paterson and Lima, 2005). In some features of its ecology, Aspergillus species are comparable to Legionella species, recognized to be water pathogens, including ability to form biofilms in water pipelines networks (Warris et al., 2003).

Mycotoxins are fungal secondary toxic metabolites produced under certain conditions to achieve a competitive advantage for mold over other species and bacteria. Those substances are resistant to heat treatment, high degree of toxicity, carcinogenic in nature and has mutagenic and teratogenic features (Adams and Moss, 2000; Martins et al., 2001). Various sources can lead to mycotoxin contamination of dairy product. Of those, indirect pathway through ingestion of contaminated feeding stuff which resulted in release of mycotoxins into milk. On the other hand, direct contamination due to mold growth on dairy products still paly important role (Seddek et al., 2016). It is advisable to monitor the concertation of mycotoxin poses major public health hazard and eradicate the source for incursion of fungal contamination into the water sources (Paterson, 2006).

Aflatoxigenic molds, comprising mainly $A$. flavus, A. parasiticus, and A. niger (Cary et al., 2005; Frisvad et al., 2005). B1, B2, G1, and $\mathrm{G} 2$, as well as two additional metabolic products, M1 and M2, are the four primary aflatoxins. (Doyle et al., 1997; Sengun et al., 2008). Both AFB1 and AFM1 are internationally classified as carcinogenic toxins belong to group 1 and group 2 human carcinogens; respectively (IARC, 2002). Hepatocellular carcinoma (HCC) is significantly correlated to Aflatoxins exposure (IARC, 2002). Chronic exposure to carcinogenic AFB1 and AFM1 in milk, especially for babies and young children, is of public health concern (Colak, 2007; Aiad and Abo El-Makarem, 2013). Many fungal species like Aspergillus niger, $A$. ochraceus, A. alliaceus, A. carbonarius have the ability to produce Ochratoxin A and Penicillium spp such as $P$. chrysogenum, $P$. verrucosum, $P$. nordicum (González-Salgado et al., 2005; Clark and Snedecker, 2006). Ochratoxin A (OTA) the most abundant and the most toxic one (Awad et al., 2012). OTA hepatotoxic, nephrotoxic, teratogenic, immunogenic and carcinogenic effects are well documented by Pattono et al. (2011) and has been classified as group 2 human carcinogenic toxin (IARC, 2002; Pattono et al., 2011). The heat resistance of AFM and OTA is unaffected by the manufacture, preparation, and storage of various dairy products (Lin et al., 2004). According to European Union Regulations (2004) and European Commission Regulation (2006), the 
international acceptable limits for AFB1 and AFM1 are 2.0-12 and $0.05 \mu \mathrm{g} / \mathrm{l}$, respectively, whereas OTA is $2-10 \mu \mathrm{g} / \mathrm{l}$ (European Commission Regulation, 2006; Coffey et al., 2009).

One of the most efficient strategies to reduce spoiling losses is to control the microbial load in the manufacturing environment. This can be accomplished by using hygienic-sanitary processes including various decontamination procedures like cleaning, sanitization and disinfection. The most appropriate active sanitizing principle for each region, as well as the concentrations used, are the most essential elements to consider in order to obtain the desired results (Rutala, 1996). The emphasis on the need for safer foods with a longer shelf life has resulted in the increased usage of chemical disinfection. The goal of disinfection is to remove germs from food-contact surfaces, preventing spoiling of raw materials and products. Most disinfection failures to reduce yeast and mold to an acceptable level are attributed to improper process parameters (disinfectant concentration, exposure duration) or a failure of the cleaning process (Langsrud et al., 2003). Furthermore, water treatment and disinfection techniques are effective in reducing the quantity of fungi in water sources.

Because of mycotoxins' thermal stability, the procedure of their removal or reduction is difficult (Teniola et al., 2005; Armando et al., 2012). Biological detoxification involves the use of microorganisms that can convert mycotoxins to less harmful compounds, as well as the correct treatment of food through fermentation (Aiko and Mehta, 2015; Ji et al., 2016). Biological detoxification is more effective, precise, and safe for the customer than physicochemical detoxification approaches (Zhu et al., 2017). Lactic acid bacteria (LAB) play an essential role in fermentation of food products especially dairy products.
Organic acids, hydrogen peroxide, bacteriocins, hydroxylated fatty acids, diacetyl, and reuterin, among other inhibitory metabolites produced by LAB, are utilized to preserve food. (Eddine et al., 2021). Streptococci and Lactobacilli species are historically used as starting cultures in the production of yoghurt. Lactic acid bacteria (LAB), especially probiotic strains, is now regarded a critical feature of yogurt quality. (Mosallaie et al., 2019). The capacity of lactic acid bacteria to bind aflatoxins in vitro and in vivo was studied (Mosallaie et al., 2019). The detoxification capacity of different LAB including Lactobacillus sp. was explored against mycotoxins. They determined that Aflatoxin had the greatest drop in concentration after 6 hours of incubation, and even after 24 hours of incubation. FAO/WHO (2002) recognized LAB as bacteria that bind and absorb mycotoxins and could possibly be utilized as supplements to reduce mycotoxins levels (Chlebicz and Śliżewska, 2020).

Therefore, the objectives of this study were:

1) Study the distribution of different fungal strains in water and raw camel's milk.

2) Determinate the concentrations of mycotoxins AFB1, AFM1, and OTA in water and raw camel's milk.

3) Calculating the Acceptable Daily Intake (ADI) of certain mycotoxins for humans.

4) Molecular identification of Aspergillus flavus strains using PCR.

5) Study the fungicidal activity of three disinfectants against Aspergillus flavus and Aspergillus ochraceus strains.

6) Evaluate the detoxification and elimination properties of LAB on Aflatoxin M1 level in yoghurt produced from camel's milk. 


\section{MATERIALS AND METHODS}

\section{Collection of samples:}

The current study was carried out in Sohag governorate to target the household animal rearing. A total of three hundred samples of water and camel milk (one hundred and fifty samples of each) were collected to determine the prevalence of mold species. In addition, the levels of AFB1, AFM1 and OTA in collected samples were estimated using HPLC. The fungicidal efficacies of different disinfectants against mycotoxins producing fungi at numerous contact times under environmental dairy condition (clean /dirty) were evaluated. Synergize ${ }^{\circledR}$ was used at dilution rate 1:256; Sodium Hypochlorite Solution $5 \%$ was used at dilution concentration of $50 \mathrm{ppm}$ and TEK-TROL was used at dilution rate 1:256. Biological reduction of Aflatoxin M1 in yoghurt by LAB. Moreover, the detoxification and elimination property of some LAB was studied. (Jooyandeh et al., 2015; Galeboe et al., 2018; Mosallaie et al., 2019).

\subsection{Milk samples:}

Fifty ml of raw milk was collected in clean sterilized Falcon $^{\mathrm{TM}} 50 \mathrm{ml}$ tubes from each animal. Immediately after collection, milk samples were placed in ice packs and delivered to the laboratory, where stored at $4{ }^{\circ} \mathrm{C}$ until analysis.

\subsection{Water samples:}

Water samples were collected from local water sources inside farmer dwellings in clean, sterile, transparent $500 \mathrm{~mL}$ glass bottles with ground glass stoppers (WHO, 1971).

\section{Preparation and serial dilutions of samples:}

Ten millimeters of the prepared samples were mixed thoroughly with $90 \mathrm{ml}$ of sterile buffered peptone water solution, and then tenfold serial dilutions were carried out according to A.P.H.A. (2004).

\section{Mold counting and identification:}

One $\mathrm{ml}$ of each diluted mixture was delivered from each dilution and carefully mixed with $10-15 \mathrm{ml}$ of malt extract agar (containing $500 \mathrm{mg}$ each of chlorotetracycline $\mathrm{HCl}$ and chloramphenicol) tempered at $45 \pm 1{ }^{\circ} \mathrm{C}$. After solidification, plates were incubated at $25{ }^{\circ} \mathrm{C}$ for 3-5 days. The growing colonies were counted and the total colonies counts were calculated. For identification, the mold colonies that had grown were counted and isolated. (Harrigan and MacCance, 1966).

Mold isolates were then inoculated onto Malt extract agar (MEA), Czapek yeast extract agar (CYA) and kept in 25\% glycerol nitrate agar $(\mathrm{G} 25 \mathrm{~N})$. Identification of the fungal species was carried out according (Pitt and Hocking, 2009).

\section{HPLC Analysis:}

High-performance liquid chromatography was used to analyze the prepared samples. The HPLC parameters are clarified in (Table 1). Estimation of mycotoxins were operated as previously decorated by ElNazami et al. (1998), with minor modifications. For this reason, Agilent HPLC 1200 Series (USA) system consisting of UV and Fluorescence detectors, quaternary pump and degasser was used. Instrument control, data acquisition and data analysis were achieved by HPLC chemstation software. The levels of mycotoxin were evaluated by comparing the peak area retention durations of the samples to the standard curves obtained from HPLC analysis of standard solutions. (Fig. 1) (Chlebicz and Śliżewska, 2020). The results of the mycotoxins were compared to the permitted limit of the guidance level of global organizations.

\section{Estimation of human daily and weekly intakes of mycotoxins from examined milk products:}

Estimated Daily and Weekly Intakes (EDI and EWI) of the examined samples were obtained according to the equations described before elsewhere (Ahmed et al., 2020; Diab et al., 2020). Moreover, the 
results were matched to the international standards organization's Acceptable Daily Intake (ADI).

\section{PCR analysis:}

According to the manufacturer's recommendations, genomic DNA was isolated from ground frozen Aspergillus flavus mycelium/spores using a Spin Column DNeasy plant minikit (Geneaid, USA). PCR was used to amplify the regulatory aflatoxin gene segment of aflatoxigenic mold. Two primer pairs ( $a f l D$ and $a f l Q$ ) were explored on the basis of the sequences of $A$. flavus aflatoxin biosynthetic genes as presented in Table (2) (Gallo et al., 2012).

A reaction mixture (25) containing $10 \mathrm{mM}$ of each primer, $5 \mathrm{U} / 1$ Taq DNA polymerase, $5 \mathrm{ng} / \mathrm{l}$ template DNA, $10 \mathrm{mM}$ dNTP mix, $\mathrm{MgCl}_{2}$-free reaction buffer, and $50 \mathrm{mM}$ $\mathrm{MgCl}_{2}$ was used to perform PCR amplifications. (1) 3-minute step at $94{ }^{\circ} \mathrm{C}$; (2) 30 cycles of the following three steps: 1 minute at $94{ }^{\circ} \mathrm{C}, 1$ minute at $57{ }^{\circ} \mathrm{C}, 1$ minute at $72{ }^{\circ} \mathrm{C}$; (3) final 10 -minute step at $72{ }^{\circ} \mathrm{C}$. To separate PCR products, $1.2 \%$ agarose gel electrophoresis in a Tris-base, acetic acid, and EDTA buffer was utilized and stained with ethidium bromide. The transilluminator was used to visualize the gel picture. The size of amplicons is measured using a 100-bp ladder (Okoth et al., 2018).

\section{Fungicidal activity of disinfectants:}

The study aimed to assess the Fungicidal activity of three disinfectants on Aspergillus flavus and Aspergillus ochraceus:

1- Synergize $^{\circledR}$ which is a multi-purpose disinfectant-cleaner formulated of Quaternary ammonium/glutaraldehyde: Alkyl (C12 67\%, C14 25\%, C16 7\%, C18 $1 \%$ ) dimethyl benzyl ammonium chloride (26.0\%), glutaraldehyde (7.0\%), inert Ingredients (67.0\%). (Neogen Food and Animal Security (India) PVT, LTD. Uchikkal Lane, Poonithura P.O. Cochin 682038 Kerala, India). Dilution rate is 1:256 to pre-cleaned surfaces.
2- Chlorine based compounds: Sodium Hypochlorite Solution 5\% available Chlorine (Superfine Manufacturing Ltd, Orchardbank Industrial Estate Forfar Angus, Scotland DD8 1TD). Dilution rate is $50 \mathrm{ppm}$ to pre-cleaned surfaces.

3- TEK-TROL: Disinfectant-Cleaner which is a synthetic detergent concentrate combined with a high powered $26 \%$ multiple chlorophenolic disinfectant: $12 \%$ ortho-Phenylphenol, $10 \%$ ortho-Benzylpara-chlorophenol, $4 \%$ para-tertiaryAmylphenol. Dilution rate is 1:256 precleaned surfaces (BIO-TEK Industries, Inc. 1380 W. Marietta St. N.W., Atlanta, GA 30318, USA).

Evaluation of the fungicidal activity was performed using the approach outlined according to European Norms (EN) (EN 1657:2005/AC:2007). The quantitative suspension test was widely used in the veterinary field to evaluate the fungicidal activity of chemical disinfectants and antiseptics. In order to test if a disinfectant is effective in clean conditions, in a suspension test, the test product (disinfectant being tested) is added directly to the test fungi in a suspension without interfering organic matter. To test if the product is effective in dirty conditions, interfering substances was used, the suspension is mixed with whole camel milk's 3\%. Exposure/contact times were 5, 10, 30 and 60 minutes for both cleaned and dirty conditions. In order to cease the disinfectant's effects, a sterile neutralizer is added immediately after the claimed contact time, and a sample of the mixture is incubated and counted. The number of fungi that have survived is counted and compared to the size of the initial culture. Dilution-neutralization method was used. A mixture of polysorbate $8030.0 \mathrm{~g} / \mathrm{l}$, saponin $30 \mathrm{~g} / \mathrm{l}$, lecithin $3 \mathrm{~g} / \mathrm{l}$, and histidine $1 \mathrm{~g} / \mathrm{l}$ for QAC-based disinfectants. Sodium thiosulfate was used for sodium hypochlorite. Tween 80 with sodium bisulphate, sodium thioglycolate, lecithin and cysteine for Glutaraldehyde. For the 
other sanitizers tested, nutrient broth with $0.5 \%$ Tween 80 and tryptone $1 \%$ was employed (Russell, 1981; Espigares et al., 2003). All disinfectants were used and handled according to manufacturer's instructions.

For each exposure time, the fungicidal effect (FE) was expressed as a $\log _{10}$ reduction factor. The formula is $\mathrm{FE}=\log 10$ NC- $\log 10 \mathrm{ND}$, where NC and ND are the $\mathrm{CFU} / \mathrm{mL}$ in the control and disinfectant, respectively. Moreover, Hernandez et al. (2000) stated that when the initial inoculums were reduced by a $\geq 4$-fold, it was suggested that the product be used as a disinfectant. This criterion is the bare minimum that must be met in order to pass a quantitative suspension test.

\section{Biological reduction of aflatoxin $\mathrm{M1}$ in yoghurt by LAB:}

Raw camel milk samples with various AFM1 residue concentrations were pasteurized for 5 minutes at $85{ }^{\circ} \mathrm{C}$ in a stainless-steel double jacket container before being chilled to the inoculation temperature $\left(40-42{ }^{\circ} \mathrm{C}\right)$. After cooling, the commercial yoghurt starter culture in lyophilized state containing Streptococcus thermophilus and Lactobacillus bulgaricus $\left(\right.$ YoFlex $^{\circledR}$ Express 2.0 Chr Hansen, Hørsholm, Denmark) was used for camel milk yoghurt preparation at a concentration of 1:1,000 according to method proposed by Galeboe et al. (2018). The inoculated milk samples were kept in sterile plastic containers and incubated at $42{ }^{\circ} \mathrm{C}$ for 4 hours in normal oxygen conditions until $\mathrm{pH}$ was 4.60 , then the fermentation process was terminated. The samples were promptly cooled and kept at $4{ }^{\circ} \mathrm{C}$ for 20 days. All analyses of the yoghurt samples were performed in triplicate directly after production, and 1, 5, 10, 15 and 20-days during cooling storage by HPLC to determine the level of AFM1 after fermentation (Mosallaie et al., 2019).

A digital $\mathrm{pH}$ meter was used to determine the $\mathrm{pH}$ of the sample (ADWA Instrutments
Kfts, ADWA Hungary Kfts Company, model AD1030, Hungary) by direct electrode immersion in samples at room temperature. Titratable acidity was assessed according to the method declared by Jooyandeh et al. (2015) as a percentage of lactic acid. Briefly, $9 \mathrm{~g}$ of sample was blended with $9 \mathrm{ml}$ of distilled water and titrated with $0.1 \mathrm{~N} \mathrm{NaOH}$ using $1 \%$ phenolphthalein (w/v) in ethanol as an indicator, to an end point of stable faint pink color for $30 \mathrm{~s}$.

\section{RESULTS}

\section{Mycological profile of water and raw camel milk}

Overall 56 and $64 \%$ of samples yielded mold spp., including water and raw camel's milk samples respectively. The mean values were $1.71 \times 10^{4}$ and $3.54 \times 10^{4} \mathrm{cfu} / \mathrm{ml}$, respectively (Table 3 ). Morphological, biochemical and microscopical examinations showed that the mold isolates were the genera, Acremonium, Alternaria, Aspergillus, Botrytis, Cladosporium, Emericella, Eurotium, Eupenicillium, Fusarium, Geotrichum, Mucor, Penicillium, Rhizopus, Scopulariopsis and Thrichoderma. Notably, Aspergillus spp. were the most abundant species isolated from water and raw camel milk samples with 10.9 and $11.6 \%$, respectively, including A. flavus, A. niger, A. ochraceus, A. fumigatus, $A$. parasiticus and $A$. sydowii. Penicillium spp. and Fusarium spp. were the second and third most abundant species detected as revealed from (Table 4).

\section{Mycotoxins contamination per type of sample}

The purity of the mycotoxins standard (AFB1, AFM1 and OTA) were determined as $99 \%$ by the UV and fluorescent detector. The HPLC calibration curves (Fig. 1) for mycotoxins AFB1, AFM1 and OTA, each one was done with five standard solutions of concentration up to $30 \mu \mathrm{g} / \mathrm{l} \mathrm{or} \mathrm{kg}$, had the following correlation coefficients: AFB $1 \mathrm{R}^{2}$ $=0.9987$ (Fig. 1A), AFM1 R $=0.998$ (Fig. 1B) and OTA $R^{2}=0.9982$ (Fig. 1C). The 
results showed the linearity of the standard curve over the range studied.

Following the mycotoxins content by validated HPLC method, water and raw camel's milk samples showed heterogeneous mixtures of mycotoxins (Table 5). In the water samples tested, aflatoxin-B1 (AFB1) and ochratoxin-A (OTA) levels were 7.97 and $8.28 \mathrm{~g} / \mathrm{l}$, respectively. Furthermore, in the raw camel milk samples tested, aflatoxin-M1 (AFM1) and ochratoxin-A (OTA) levels were 1.89 and $1.69 \mathrm{~g} / \mathrm{l}$, respectively. Almost all assessed AFB1, AFM1, and OTA levels were above the European Commission Regulation's permitted limits. (European Commission Regulation, 2006; Coffey et al., 2009). On light of the above, 36 and $43 \%$ of water samples contaminated with AFB1 and OTA, respectively; and 60 and $31 \%$ of raw camel milk samples contaminated with AFM1 and OTA, respectively exceeded the maximum permissible limits according to the European Regulations (Table 6).

The acceptable intakes (AI) and the estimated intakes of mycotoxins (EI) for adults and children were reported in relation to time, both per day and per week (Table 7). The estimated daily intake (EDI) of mycotoxins (AFB1, AFM1 and OTA) in water and raw camel milk samples were evaluated by using the consumed amount of the water and raw camel milk and the estimated mean mycotoxin concentrations in each sample type, taking into account the average body weight of the different groups (children and adult). In 46.7 and $26 \%$ of water samples contaminated with AFB1 and OTA, respectively, the EDI values were substantially higher than the recommended daily intakes (ADI) of infants and adults; 0.0 and $0.014 \mathrm{~g} / \mathrm{kg}$ b.w. Also, the EDI levels were much exceeded over their acceptable daily intakes (ADI); 0.002 and $0.014 \mu \mathrm{g} / \mathrm{kg}$ b.w. in 12 and $10 \%$ of raw camel milk samples contaminated with AFM1 and OTA, respectively (Kuiper-
Goodman, 1990; JECFA, 2007; Brera et al., 2008) (Table 7).

\section{Amplification patterns of aflatoxin biosynthesis genes}

Electrophoretic banding pattern of aflD (nor-1) and aflQ (ordA) designed to aflatoxin biosynthesis genes related to their ability to produce AFB1. The structural genes $a f l D$ and $a f l Q$; were detected from morphologically identified A. flavus. aflD and $a f l Q$ used as demonstration to confirm the presence of aflatoxigenic A. flavus strains, when opposed to traditional plating procedures, this allows for easy identification. The sizes of the DNA fragments (800 and $757 \mathrm{bp}$ ) were calculated using a commercial DNA ladder 100 bp (Fig. $2 \mathrm{~A}$ and $\mathrm{B}$ ).

\section{Antifungal activity (log reduction) of disinfectants}

The antifungal activities were varied between the tested disinfectants, the recommended concentration applied, as well as the species and isolates susceptibility used in the test under clean /dirty condition (Table 8).

Sodium hypochlorite achieved $3.6 \mathrm{log}$ reduction of $A$. flavus at 5 minutes under clean condition which seem to be much lower with $1.5 \mathrm{log}$ reduction in the presence of milk contamination. Increasing the contact time to one hour results in improving the killing power of Sodium hypochlorite / clean condition reaching 6.8 $\log$ reduction while limited improving was observed for dirty condition with $3.8 \mathrm{log}$ reduction. Furthermore, Sodium hypochlorite showed poor and reduced efficacy against $A$. ochraceus under dirty dairy environment as only $1.9 \mathrm{log}$ reduction / 5 minutes and even after 15 minutes, still only achieved $2.9 \quad \log$ reduction. In addition, it achieved a reduction of 4.2 and $7.2 \log$ of A. ochraceus after 5 and $60 \mathrm{~min}$ of exposure to this agent at a concentration of $50 \mathrm{ppm}$. 
Quaternary ammonium/glutaraldehyde based disinfectant was the utmost effective disinfectant against the molds assessed under clean condition at dilution rate is 1:256. It showed higher efficacy against $A$. ochraceus resulting in $4.5,5.6,6.5$ and 7 $\log$ reduction after $5,10,15$ and 30 minutes' exposure times respectively. On the other hand, it exhibited lower efficacy against $A$. flavus achieving 3.8, 4.3, 4.5 and 5.7 at the same contact time under clean condition. Upon using of Quaternary ammonium/glutaraldehyde at dirty environment dairy condition, the agent could achieve good efficacy against $A$. ochraceus after at least exposure time of 15 minutes with $3.2 \mathrm{log}$ reduction while exposure to shorter time showed reduced efficacy. In addition, the disinfectant showed reduced efficacy against $A$. flavus and required a minimum 60 minutes' exposure time to exhibit improved killing power resulting $4.5 \mathrm{log}$ reduction. Exposure of A. flavus to shorter contact times of 5 , 10,15 , and 30 minutes' causing 1.3, 2.1, 2.5 and $2.6 \log$ reduction which seem to be reduced efficacy.

Multiple chlorophenolic disinfectants result in reduction ranged from 3.3 to $6.7 \mathrm{log}$ for both $A$. flavus and $A$. ochraceus at 1:256 concentrations without interfering substance. Using of chlorophenolic disinfectant in the presence of milk contamination found to have poor efficacy against $A$. flavus at short contact times which only result in $0.8 \mathrm{log}$ reduction after 5 minutes. Even after exposure time of 10, 15, 30 minutes, it still showed reduced efficacy against $A$. flavus with 1.2,1.6 and $2.3 \mathrm{log}$ reduction respectively. Under the same dirty condition/concentration, at exposure time of 15 and 30 minutes, it exhibited good efficacy with 3.3 and $3.6 \mathrm{log}$ reducing of $A$. ochraceus.

\section{Mycelial growth inhibition assay}

Mycelial growth assays revealed that both Sodium hypochlorite and Synergize treatments inhibited mycelial growth at varied levels of tested A. flavus isolates. (Fig. 3A and B). Initial screening was done after two day of mold growth; A. flavus was sensitive to both disinfectants. However, the inhibition zone was $7.33 \mathrm{~mm}$ in diameter for Synergize biocide at the early stage of mold growth while Sodium hypochlorite induced inhibition zone of $3.21 \mathrm{~mm}$ at $1: 256$ and $50 \mathrm{ppm}$ concentration for Synergize and Sodium hypochlorite respectively.

Quaternary ammonium/glutaraldehyde based disinfectant achieved consistent pattern of inhibition of mycelial growth, throughout 15-day incubation period, which was recorded in A. flavus growth with minor variation of the reported inhibition zones at the two concentration used (SZ1/1:256 and SZ2 1:128). On the other hand, inhibition pattern of mycelium growth of $A$. flavus after exposure to Sodium hypochlorite at various incubation period using two concentrations (SH1/50 ppm and SH2/100 ppm) showed that the inhibition power was sharply reduced starting from day 5 of incubation till the end of incubation period at 15 days when inhibition zone was disappeared.

\section{AFM1 microbial reduction in yoghurt by LAB:}

Yoghurt starter culture containing Streptococcus and Lactobacillus spp. were characterized by their diverse capability to reduce AFM1 in yoghurt. In merely after 5 days of incubation, a reduction of AFM1 concentration (statistically significant) was noticed, a reduction of $1.5 \mu \mathrm{g} / \mathrm{kg}(24.6 \%$ reduction) was recorded compared to the initial AFM1 concentration of $2.03 \mu \mathrm{g} / \mathrm{ml}$ $(0 \%$ reduction). In the subsequent incubation period (15 days), further AFM1 concentration reduction was observed (1.1 $\mu \mathrm{g} / \mathrm{kg}$ with $45.9 \%$ reduction). After 20 days of incubation, the concentration of mycotoxin was $0.9 \mu \mathrm{gg} / \mathrm{kg} \quad(55.7 \%$ reduction). Therefore, a reduction of $55.7 \%$ in compared to the initial mycotoxin concentration were obtained. Based on 
these results, the analysis allowed selection of Streptococcus and Lactobacillus spp. characterized by the best detoxification and reduction capabilities (Fig. 4).

The changes in the tested samples $\mathrm{pH}$ during the 20-day cold storage $\left(4{ }^{\circ} \mathrm{C}\right)$ and after completion of the yoghurt fermentation are reported in (Fig. 5A). The average values of $\mathrm{pH}$ ranged from 3.95 to 4.55 during the storage period. The highest $\mathrm{pH}$ value (4.55) was recorded at 0 -day just after production of yoghurt and the lowest $\mathrm{pH}$ value (3.95) was recorded at the end of storage (20-day sample). The titratable acidity (TA) values of yoghurt samples during storage period were significantly changed (Fig. 5B). The TA values of LAB samples increased meaningfully throughout storage time started from 1.17 to $1.82 \%$ at 0 - and 20-day cold storage $\left(4{ }^{\circ} \mathrm{C}\right)$, respectively. The increase in TA values of fermented milks is a common phenomenon during cold storage.

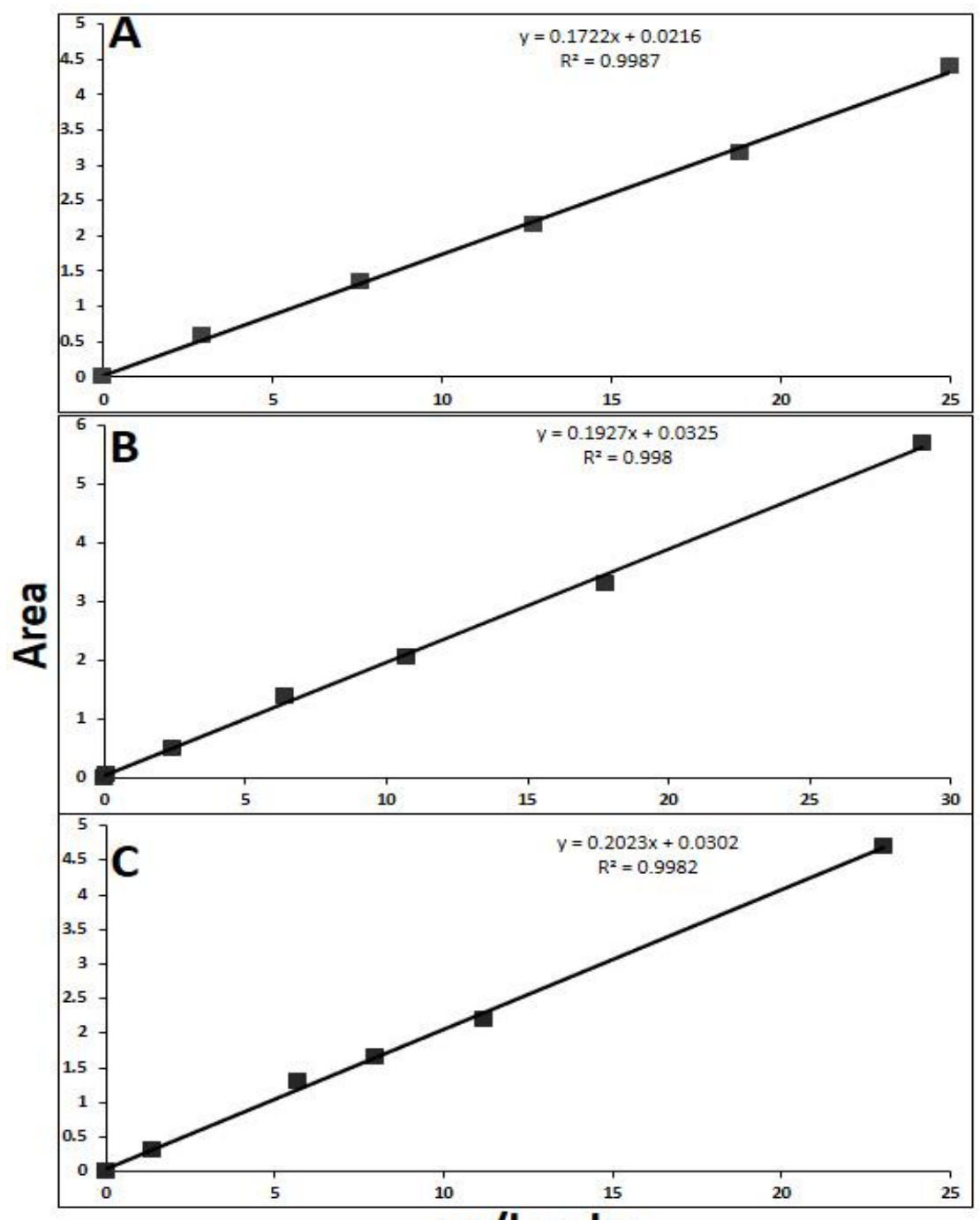

$\mu \mathrm{g} / \mathrm{l}$ or $\mathrm{kg}$

Fig. 1: Calibration curves used in HPLC detection of mycotoxins standards done with various concentrations; Aflatoxin B1 (A), Aflatoxin M1 (B) and Ochratoxin A (C). 


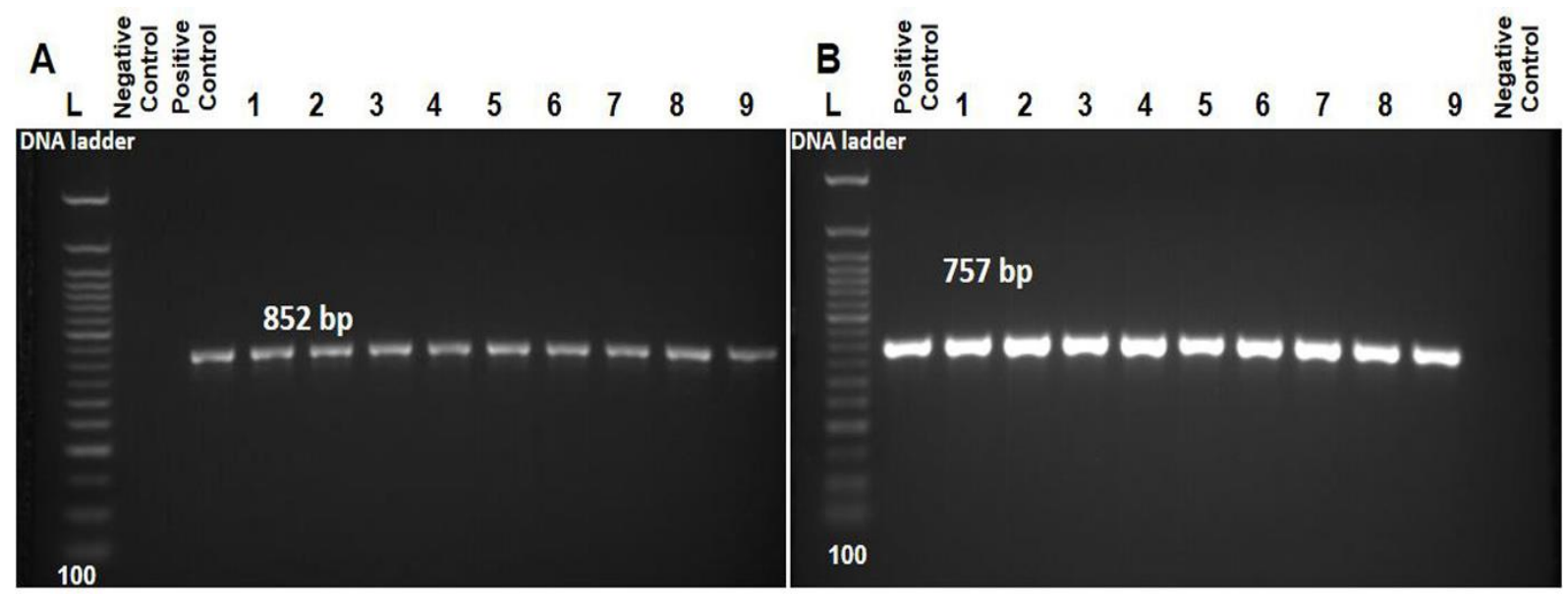

Fig. 2: PCR products of amplified of aflatoxigenic (A and B) genes identified in Aspergillus flavus and Aspergillus parasiticus visualized on agarose gel electrophoresis. The expected molecular size of amplified DNA: $852 \mathrm{bp}$ for aflD (nor-1) gene (A) and $757 \mathrm{bp}$ for aflQ (ordA) gene (B) Lane 1-9: samples and Lane (L) DNA ladder $100 \mathrm{bp}$.

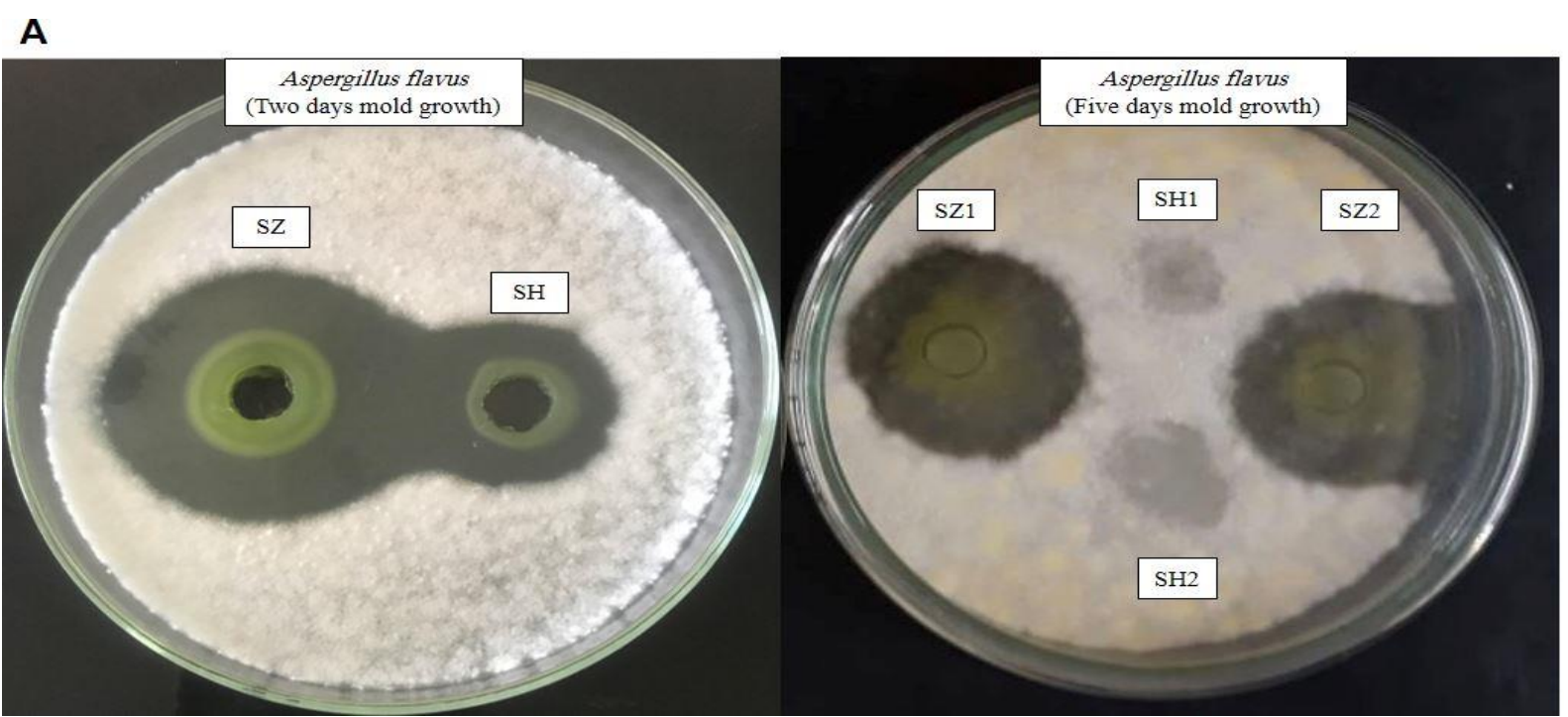

Fig. 3 (A)

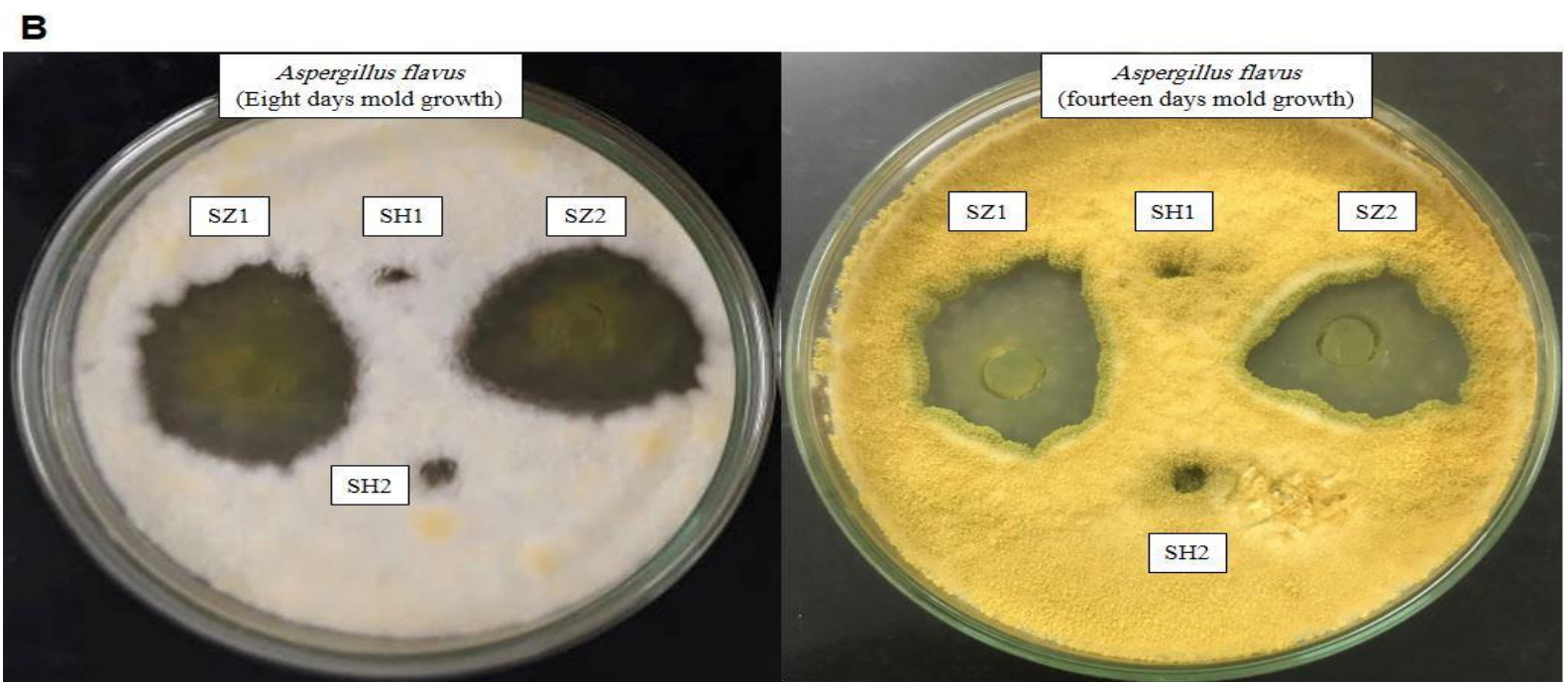

\section{Fig. 3 (B)}

Fig. 3: Antifungal Inhibitory activity of Synergize ${ }^{\circledR}$ and Sodium Hypochlorite disinfectants against Aspergillus flavus after (A) two and five days and (B) eight and fourteen days' mold growth. 


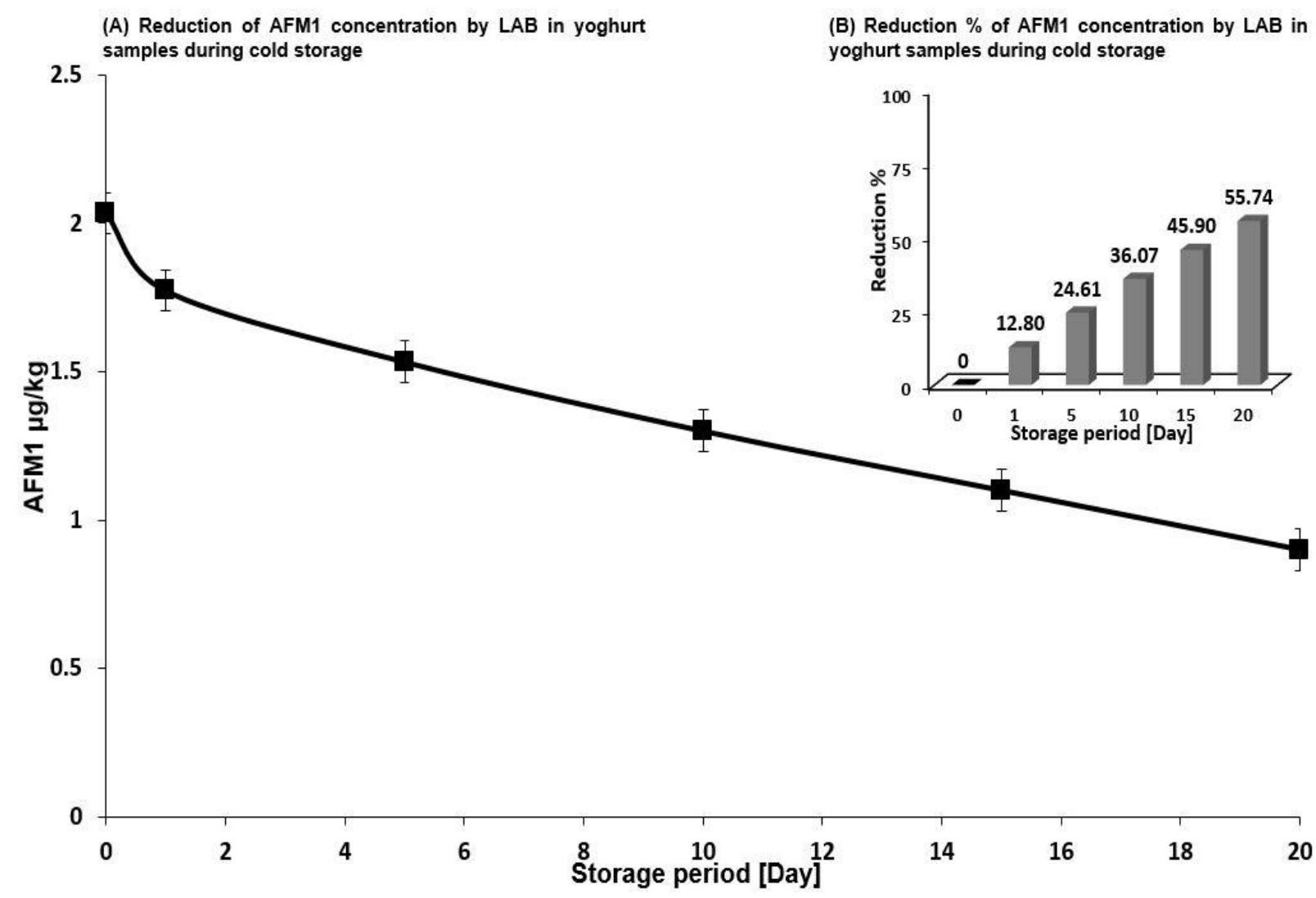

Fig. 4: Reduction of AFM1 concentration by LAB in yoghurt samples during the cold storage. The data is presented as reduction in AFM1 concentration $(\mu \mathrm{g} / \mathrm{kg})$. (Inset) Reduction $\%$ of AFM1 concentration by LAB in yoghurt samples during the cold storage. The assay was performed in triplicate.

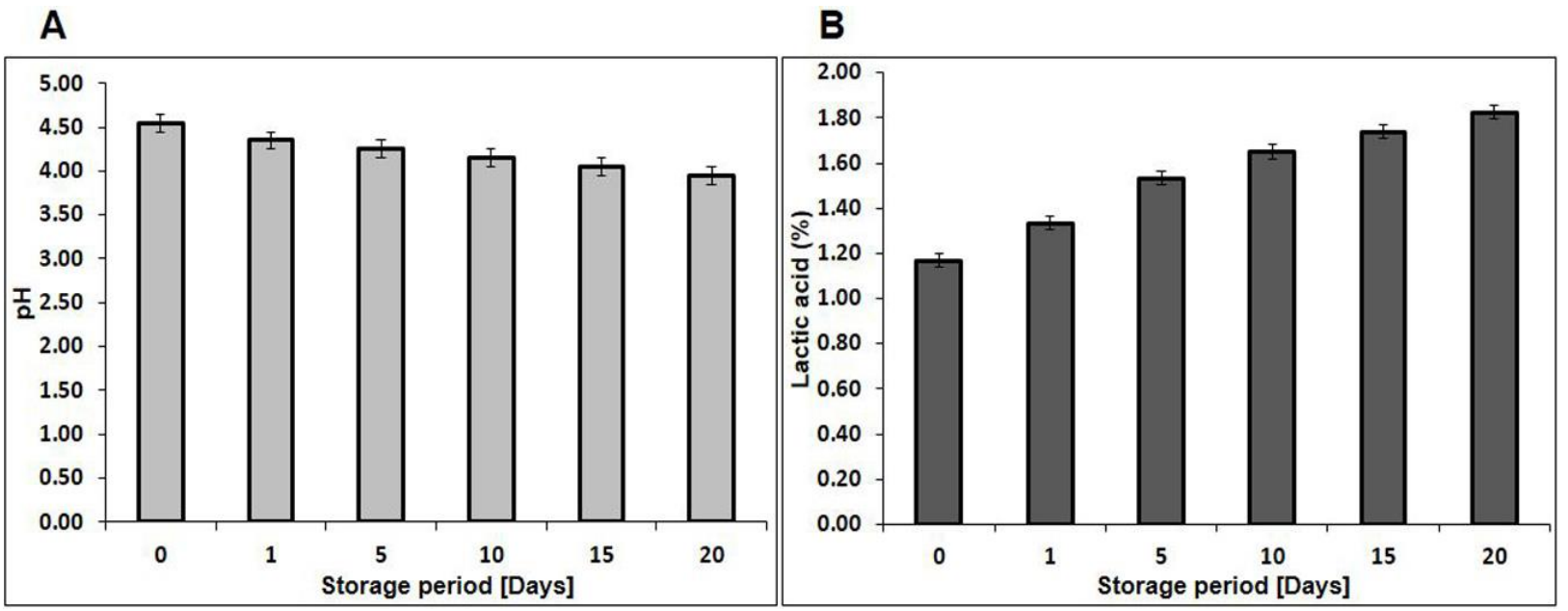

Fig. 5: (A) Change in the $\mathrm{pH}$ level of yoghurt samples during the cold storage. (B) Change in the titratable acidity $\%$ of yoghurt samples during the cold storage. 
Table 1: HPLC analysis parameters.

\begin{tabular}{llll}
\hline \multirow{2}{*}{ Parameter } & \multicolumn{3}{c}{ Mycotoxins } \\
\cline { 2 - 4 } & Aflatoxin B1 & Aflatoxin M1 & Ochratoxin A \\
\hline Column heating & - & $\mathbf{5 0}$ 'C & - \\
\hline Mobile phase & $\begin{array}{l}\text { Water/acetonitrile } \\
\text { /methanol } \\
(60: 30: 10)\end{array}$ & $\begin{array}{l}\text { methanol: } \\
(97: 3)\end{array}$ & $\begin{array}{l}\mathrm{H}_{2} \mathrm{O} / \text { acetonitrile/ } \\
\text { acetic acid } \\
(49.5: 49.5: 1)\end{array}$ \\
\hline $\begin{array}{l}\text { Fluorescent detector } \lambda(\mathrm{nm}) \\
(\text { excitation and emission) }\end{array}$ & 360 and $420 \mathrm{~nm}$ & - & 333 and $460 \mathrm{~nm}$ \\
\hline UV detector $\lambda(\mathrm{nm})$ & - & $233 \mathrm{~nm}$ & - \\
\hline Flow $(\mathrm{ml} / \mathrm{min})$ & 1 & 1 & 1 \\
\hline References & Chlebicz and & $\begin{array}{l}\text { Zakaria } \text { et al., } \\
(2019)\end{array}$ & Visconti et al., \\
\hline
\end{tabular}

Table 2: PCR protocol including primer sequences, Amplicon size and amplification reactions a.

\begin{tabular}{|c|c|c|c|c|c|}
\hline \multicolumn{3}{|c|}{ Target gene } & \multicolumn{2}{|c|}{ Primers sequences } & $\begin{array}{c}\text { Amplified } \\
\text { segment (bp) }\end{array}$ \\
\hline \multirow{2}{*}{ aflD (nor-1) } & \multicolumn{2}{|c|}{ AflD-lfor } & \multicolumn{2}{|c|}{ 5'-CACTTAGCCATCACGGTCA-3' } & \multirow{2}{*}{852} \\
\hline & \multicolumn{2}{|c|}{ AflD-2rev } & \multicolumn{2}{|c|}{ 5'-GAGTTGAGATCCATCCGTG-3 } & \\
\hline \multirow{2}{*}{$\operatorname{afl} Q(\operatorname{ord} \mathrm{A})$} & \multicolumn{2}{|c|}{ AflQ-lfor } & \multicolumn{2}{|c|}{ 5' -TCGTCCTTCCATCCTCTTG-3' } & \multirow{2}{*}{757} \\
\hline & \multicolumn{2}{|c|}{ AflQ-2rev } & \multicolumn{2}{|c|}{ 5' -ATGTGAGTAGCATCGGCATTC-3' } & \\
\hline \multicolumn{6}{|c|}{ a Primer design and amplification process steps as published by Gallo et al., 2012.} \\
\hline \multicolumn{6}{|c|}{$\begin{array}{l}\text { Table 3: Statistical analytical results of mold count (Total mold count } / \mathrm{ml}) \text { in examined water } \\
\text { and raw camel milk samples }(\mathrm{N}=150)\end{array}$} \\
\hline \multirow{2}{*}{ Samples } & \multicolumn{2}{|c|}{$\begin{array}{l}\text { Positive } \\
\text { samples }\end{array}$} & \multicolumn{3}{|c|}{ cfu/ml } \\
\hline & No & $\%$ & Minimum & Maximum & Mean \pm S.E \\
\hline Water & 84 & 56 & $3.30 \times 10^{1}$ & $5.50 \times 10^{4}$ & $1.71 \times 10^{4} \pm 3.84 \times 10^{3}$ \\
\hline $\begin{array}{l}\text { Raw camel } \\
\text { milk }\end{array}$ & 96 & 64 & $1.30 \times 10^{2}$ & $3.30 \times 10^{4}$ & $1.45 \times 10^{4} \pm 2.53 \times 10^{3}$ \\
\hline
\end{tabular}


Table 4: Frequency distribution of identified mold isolates in examined samples $(\mathrm{N}=150)$

\begin{tabular}{|c|c|c|c|c|}
\hline \multirow{2}{*}{ Isolates of mold } & \multicolumn{2}{|c|}{ Water } & \multicolumn{2}{|c|}{ Raw camel milk } \\
\hline & No & $\%$ & No & $\%$ \\
\hline Acremonium strictum & 1 & $1 \%$ & 2 & $2 \%$ \\
\hline Alternaria alternate & 0 & $0 \%$ & 0 & $0 \%$ \\
\hline Aspergillus flavus & 10 & $11 \%$ & 11 & $11 \%$ \\
\hline Aspergillus fumigatus & 3 & $3 \%$ & 4 & $2 \%$ \\
\hline Aspergillus niger & 6 & $7 \%$ & 5 & $6 \%$ \\
\hline Aspergillus ochraceus & 5 & $5 \%$ & 6 & $5 \%$ \\
\hline Aspergillus parasiticus & 6 & $7 \%$ & 4 & $5 \%$ \\
\hline Aspergillus sydowii & 3 & $3 \%$ & 3 & $1 \%$ \\
\hline Aspergillus terreus & 2 & $2 \%$ & 3 & $1 \%$ \\
\hline Botrytis cinerea & 1 & $1 \%$ & 2 & $1 \%$ \\
\hline Cladosporium spp. & 4 & $4 \%$ & 6 & $7 \%$ \\
\hline Emericella nidulans & 2 & $2 \%$ & 0 & $0 \%$ \\
\hline Eurotium chevalieri & 0 & $0 \%$ & 0 & $0 \%$ \\
\hline Eupenicillium spp. & 5 & $5 \%$ & 3 & $4 \%$ \\
\hline Fusarium chlamydosporum & 3 & $3 \%$ & 3 & $4 \%$ \\
\hline Fusarium coeruleum & 0 & $0 \%$ & 1 & $1 \%$ \\
\hline Fusarium graminaerum & 6 & $7 \%$ & 4 & $5 \%$ \\
\hline Geotrichum candidum & 3 & $3 \%$ & 4 & $5 \%$ \\
\hline Mucor circinelloides & 1 & $1 \%$ & 3 & $4 \%$ \\
\hline Mucor racemosus & 2 & $2 \%$ & 1 & $1 \%$ \\
\hline Penicillium chrysogenum & 5 & $5 \%$ & 7 & $8 \%$ \\
\hline Penicillium citreonigrum & 7 & $8 \%$ & 5 & $6 \%$ \\
\hline Penicillium citrinum & 5 & $5 \%$ & 1 & $1 \%$ \\
\hline Penicillium digitatum & 0 & $0 \%$ & 4 & $5 \%$ \\
\hline Penicillium glabrum & 0 & $0 \%$ & 0 & $0 \%$ \\
\hline Penicillium Paneum Frisvad & 1 & $1 \%$ & 1 & $1 \%$ \\
\hline Penicillium paxilli Bainier & 1 & $1 \%$ & 0 & $0 \%$ \\
\hline Penicillium purpurogenum Stoll & 1 & $1 \%$ & 0 & $0 \%$ \\
\hline Penicillium rubrum & 0 & $0 \%$ & 1 & $1 \%$ \\
\hline Rhizopus microsporus & 3 & $3 \%$ & 4 & $5 \%$ \\
\hline Scopulariopsis brevicaulis & 3 & $3 \%$ & 3 & $4 \%$ \\
\hline Thrichoderma spp. & 3 & $3 \%$ & 4 & $5 \%$ \\
\hline Total & 92 & $100 \%$ & 95 & $100 \%$ \\
\hline
\end{tabular}

Table 5: Incidence and Statistical analytical results of mycotoxins $(\mu \mathrm{g} / \mathrm{l})$ in examined samples $(\mathrm{N}=150)$

\begin{tabular}{|c|c|c|c|c|c|c|c|c|c|c|c|c|c|c|c|}
\hline \multirow{3}{*}{ Sample } & \multicolumn{5}{|c|}{ Aflatoxin B1 } & \multicolumn{5}{|c|}{ Aflatoxin M1 } & \multicolumn{5}{|c|}{ Ochratoxin A } \\
\hline & \multicolumn{2}{|c|}{$\begin{array}{l}\text { Positive } \\
\text { samples }\end{array}$} & \multirow[t]{2}{*}{ Minimum } & \multirow[t]{2}{*}{ Maximum } & \multirow{2}{*}{$\begin{array}{c}\text { Mean } \\
\pm \\
\text { S.E }\end{array}$} & \multicolumn{2}{|c|}{$\begin{array}{l}\text { Positive } \\
\text { samples }\end{array}$} & \multirow[t]{2}{*}{ Minimum } & \multirow[t]{2}{*}{ Maximum } & \multirow{2}{*}{$\begin{array}{c}\text { Mean } \\
\pm \\
\text { S.E }\end{array}$} & \multicolumn{2}{|c|}{$\begin{array}{l}\text { Positive } \\
\text { samples }\end{array}$} & \multirow[t]{2}{*}{ Minimum } & \multirow[t]{2}{*}{ Maximum } & \multirow{2}{*}{$\begin{array}{c}\text { Mean } \pm \\
\text { S.E }\end{array}$} \\
\hline & No & $\%$ & & & & No & $\%$ & & & & No & $\%$ & & & \\
\hline Water & 70 & 47 & 0.20 & 19.5 & $\begin{array}{c}7.97 \\
\pm \\
0.43\end{array}$ & - & - & - & - & - & 40 & 27 & 0.30 & 14.4 & $\begin{array}{c}8.28 \pm \\
0.35\end{array}$ \\
\hline
\end{tabular}


Table 6: Incidence of mycotoxins levels exceeding the Maximum Permissible Limit $(\mu \mathrm{g} / \mathrm{l})$ in examined samples $(\mathrm{N}=150)$

\begin{tabular}{|c|c|c|c|c|c|c|}
\hline \multirow{3}{*}{ Mycotoxins } & \multicolumn{3}{|c|}{ Water } & \multicolumn{3}{|c|}{ Raw camel milk } \\
\hline & \multirow{2}{*}{$\begin{array}{l}\text { MPL } \\
(\mu \mathrm{g} / \mathrm{l})\end{array}$} & \multicolumn{2}{|c|}{$>$ MPL } & \multirow{2}{*}{$\begin{array}{l}\text { MPL } \\
(\mu \mathrm{g} / \mathrm{l})\end{array}$} & \multicolumn{2}{|c|}{$>$ MPL } \\
\hline & & $\begin{array}{l}\text { No. of } \\
\text { samples }\end{array}$ & $\%$ & & $\begin{array}{c}\text { No. of } \\
\text { samples }\end{array}$ & $\%$ \\
\hline Aflatoxin B1 & $2-12^{a}$ & 25 & 36 & - & - & - \\
\hline Aflatoxin M1 & - & - & - & $0.05^{\mathrm{a}}$ & 27 & 60 \\
\hline Ochratoxin A & $2-10^{a}$ & 17 & 43 & $3.0^{\mathrm{b}}$ & 8 & 31 \\
\hline
\end{tabular}

a: European Commission Regulation (2006)

b: Coffey et al. (2009)

Table 7: Comparative analysis of the AI with EI ( $\mu \mathrm{g} / \mathrm{kg}$ b.w.) of mycotoxins from examined samples for children and adult.

\begin{tabular}{|c|c|c|c|c|c|c|c|c|c|c|c|c|}
\hline \multirow{3}{*}{ Mycotoxins } & \multirow{3}{*}{ ADI } & \multirow{3}{*}{ PTWI } & \multicolumn{2}{|c|}{ Samples } & \multicolumn{4}{|c|}{ Children } & \multicolumn{4}{|c|}{ Adult } \\
\hline & & & \multirow{2}{*}{$\begin{array}{c}\text { Type } \\
\text { of } \\
\text { sample } \\
\end{array}$} & \multirow{2}{*}{$\begin{array}{l}\text { Mean } \\
\text { conc. } \\
(\mu \mathrm{g} / \mathrm{l})\end{array}$} & \multicolumn{2}{|r|}{ DI } & \multicolumn{2}{|r|}{ WI } & \multicolumn{2}{|r|}{ DI } & \multicolumn{2}{|r|}{ WI } \\
\hline & & & & & EDI & $>$ ADI & EWI & $>$ PTWI & EDI & $>$ ADI & EWI & $>$ PTWI \\
\hline \multirow{2}{*}{$\begin{array}{l}\text { Aflatoxin } \\
\text { B1 }\end{array}$} & \multirow[b]{2}{*}{$0.0^{\mathrm{a}}$} & \multirow[b]{2}{*}{0.0} & Water & 7.97 & 0.35 & $70(46.7 \%)$ & 2.45 & $70(46.7 \%)$ & 0.37 & $70(46.7 \%)$ & 2.57 & $70(46.7 \%)$ \\
\hline & & & $\begin{array}{c}\text { Raw } \\
\text { camel } \\
\text { milk }\end{array}$ & - & - & - & - & - & - & - & - & - \\
\hline \multirow[b]{2}{*}{$\begin{array}{l}\text { Aflatoxin } \\
\text { M1 }\end{array}$} & \multirow[b]{2}{*}{$0.002^{b}$} & \multirow[b]{2}{*}{0.014} & Water & - & - & - & - & - & - & - & - & - \\
\hline & & & $\begin{array}{c}\text { Raw } \\
\text { camel } \\
\text { milk }\end{array}$ & 1.89 & 0.02 & $18(12.0 \%)$ & 0.16 & $18(12.0 \%)$ & 0.01 & $15(10.0 \%)$ & 0.04 & $15(10.0 \%)$ \\
\hline \multirow[b]{2}{*}{$\begin{array}{c}\text { Ochratoxin } \\
\text { A }\end{array}$} & \multirow[b]{2}{*}{$0.014^{\mathrm{c}}$} & \multirow[b]{2}{*}{0.098} & Water & 8.28 & 0.36 & $39(26.0 \%)$ & 2.55 & $39(26.0 \%)$ & 0.38 & $40(26.7 \%)$ & 2.68 & $40(26.7 \%)$ \\
\hline & & & $\begin{array}{c}\text { Raw } \\
\text { camel } \\
\text { milk }\end{array}$ & 1.69 & 0.02 & $15(10 \%)$ & 0.14 & $15(10 \%)$ & 0.01 & $0(0 \%)$ & 0.04 & $0(0 \%)$ \\
\hline
\end{tabular}

$\begin{array}{lll}\text { a: Brera } \text { et al. (2008) } & \text { b: Kuiper-Goodman (1990) } & \text { c: JECFA (2007) }\end{array}$

Table 8: Log Reduction Values of Disinfectants-Treated Aspergillus flavus and Aspergillus ochraceus in suspension at various contact times under clean /dirty environment dairy condition.

\begin{tabular}{|c|c|c|c|c|c|c|c|c|c|c|c|c|}
\hline \multirow{6}{*}{$\begin{array}{l}\text { Aspergillus } \\
\text { flavus }\end{array}$} & \multirow{3}{*}{$\begin{array}{c}\begin{array}{c}\text { Exposure duration } \\
\text { /temperature }\end{array} \\
\text { Disinfectant }\end{array}$} & \multirow{3}{*}{$\begin{array}{c}\text { zero } \\
\log \\
\text { count } \\
\text { cfu/ml } \\
\end{array}$} & \multicolumn{2}{|c|}{5 minutes } & \multicolumn{2}{|c|}{10 minutes } & \multicolumn{2}{|c|}{15 minutes } & \multicolumn{2}{|c|}{30 minutes } & \multicolumn{2}{|c|}{60 minutes } \\
\hline & & & \multicolumn{10}{|c|}{$\log$ reduction cfu/ml } \\
\hline & & & clean & dirty & clean & dirty & clean & dirty & clean & dirty & clean & dirty \\
\hline & Synergize $^{\circledR}$ & \multirow{3}{*}{$8 \log _{10}$} & 3.8 & 1.3 & 4.3 & 2.1 & 4.5 & 2.5 & 5.7 & 2.6 & 7.4 & 4.5 \\
\hline & Sodium Hypochlorite & & 3.6 & 1.5 & 3.9 & 1.8 & 4.3 & 2.3 & 4.8 & 3.2 & 6.5 & 3.8 \\
\hline & Tek-Trol & & 3.3 & 0.8 & 3.7 & 1.2 & 4 & 1.7 & 4.5 & 2.3 & 6.2 & 3.5 \\
\hline \multirow{6}{*}{$\begin{array}{c}\text { Aspergillus } \\
\text { ochraceus }\end{array}$} & $\begin{array}{c}\text { Exposure duration } \\
\text { /temperature }\end{array}$ & zero & $5 \mathrm{~m}$ & utes & $10 \mathrm{~m}$ & lutes & $15 \mathrm{~m}$ & hutes & $30 \mathrm{~m}$ & utes & $60 \mathrm{~m}$ & lutes \\
\hline & \multirow{2}{*}{ Disinfectant } & \multirow{2}{*}{$\begin{array}{c}\log \\
\text { count } \\
\text { cfu/ml } \\
\end{array}$} & \multicolumn{10}{|c|}{$\log$ reduction $\mathrm{cfu} / \mathrm{ml}$} \\
\hline & & & clean & dirty & clean & dirty & clean & dirty & clean & dirty & clean & dirty \\
\hline & Synergize $^{\circledR}$ & \multirow{3}{*}{$8 \log _{10}$} & 4.5 & 2.3 & 5.6 & 2.6 & 6.5 & 3.2 & 7 & 3.5 & 7.5 & 4.6 \\
\hline & Sodium Hypochlorite & & 4.2 & 1.9 & 5.2 & 2.4 & 5.9 & 2.9 & 6.4 & 3.3 & 7.2 & 4.5 \\
\hline & Tek-Trol & & 3.4 & 2.0 & 4.9 & 2.6 & 5.4 & 3.3 & 6.2 & 3.6 & 6.7 & 4.3 \\
\hline
\end{tabular}

The scale is divided into five comparative parameters (Bernardi et al., 2018):

- Maximum efficacy=when reducing the fungal count by at least $4 \log$

- Good efficacy=fungal count reduced from 3.9 to $3 \mathrm{log}$;

- Reduced efficacy=fungal count reduced from 2.9 to $2 \mathrm{log}$;

- Poor efficacy=fungal count reduced from 1.9 to $1 \mathrm{log}$;

- Inefficacy or no effect=when the microbial population remained unchanged. 


\section{DISCUSSION}

Milk have been associated with many health benefits including bioactive peptide, antioxidant, vitamins, highly absorbable minerals and other biologically active components (Bhat and Bhat, 2011). However, the methods of production, transportation, handling, storage and sale of milk may drive to contamination by different fungal pathogens and allow the development of heterogeneous mycotoxins mixtures. The prevalence and count of mold in examined raw camel milk samples collected from Sohag governorate, Upper Egypt declared that $64 \%$ of the samples were contaminated with fungi more than the permitted limit according to National Standards Organizations $(<10 \quad \mathrm{cfu} / \mathrm{ml})$ (EOSQC, 2005). These findings revealed that the camel milk samples tested had a high level of fungal contamination. This is due to failure to comply with hygienic standards during milking and manufacturing, as well as lack of refrigeration during raw milk storage and distribution. Moreover, the obtained results agreed with similar findings reported by researchers worldwide. They declared in majority of the places tested, milk samples are contaminated with mold and didn't fulfill with the permitted level (Benkerroum et al., 2003; El-Ziney and Al-Turki, 2007; Kaindi et al., 2011; Ismaili et al., 2019).

Mold is an environmental contaminant that can survive at a wide range of temperatures, and its presence in raw milk could be ascribed to milkers' reluctance to wash their hands or the camel udder before milking, milking in an open air (strong winds, dust), lack of water and cooling facilities, storage and transportation of milk in plastic containers under ambient temperature (Ismaili et al., 2019). Pitt and Hocking (1997) mentioned that high mold counts in milk are rare because milk's natural $\mathrm{pH}$ lead to cause predominance of bacteria. Molds can develop in a broad range of $\mathrm{pH} 2-9$, according to the FAO (1992), and can alter the $\mathrm{pH}$ of milk to around 4-6.5 to help their development followed by induction of undesirable spoilage changes such as color defects, off-flavor, changes in texture and rancidity (Mislivec et al., 1992). Also, some mold species are considered to be a potential human health and food safety hazard owing to their ability to produce mycotoxins (Ahmed et al., 2020).

Notably, a total of 32 different mold species were identified from samples of raw camel milk. Aspergillus spp. were the most abundant mold species with $11.6 \%$ of the total number of molds. These results are in parallel with previously reported data by ElZiney and Al-Turki (2007), Kaindi et al. (2011) and Ismaili et al. (2019). Aspergillus species including (A. flavus, A. fumigatus, A. niger, A. ochraceus, A. parasiticus, A. sydowii) are potential contaminant to raw milk and linked to several human disorders including infection (aspergillosis), mycotoxicosis (Gemeda et al., 2014). Moreover, Aspergillus is an important mold genus in foods especially milk and milk products causing spoilage and biodeterioration especially in tropical and subtropical weather (Hocking, 2006; Pitt and Hocking, 2009). Also, Because of their ability to produce a wide spectrum of mycotoxins dangerous to humans and animals, Aspergillus is the most important mycotoxigenic fungus. The most significant impact on public health mycotoxins produced by Aspergillus are aflatoxins (A. flavus and A. parasiticus) and ochratoxin A (A. ochraceus, A. niger and A. carbonarius) (Zain, 2011). While presence of AFM1 in raw milk because of carryovers of AFB1 from contaminated animal feed to milk (Amer and Ibrahim, 2010). Moreover, Drusch and Aumann (2005) stated that mycotoxins diffusion into the food can occur without any symptoms of mycelium growth. As a result, the lack of mold does not guarantee that food is free from mycotoxins.

The obtained data proved that examined raw camel milk samples are contaminated with heterogeneous mycotoxins mixtures 
including AFM1 and OTA. Moreover, a total of 30 and $17 \%$ of raw camel milk samples were contaminated with AFM1 and OTA and the concentrations were 1.89 and $1.69 \mu \mathrm{g} / \mathrm{l}$, respectively. 60 and $31 \%$ of the examined milk samples contain mycotoxins concentrations more than the permissible limits declared by European Commission Regulation (European Commission Regulation, 2006; Coffey et al., 2009). The findings are fundamentally consistent with prior investigations, which stated that, the presence of mycotoxins residues in spoilt raw milk samples above the acceptable limit imposed by international regulation guidelines, indicating a major public health issue. (Rahimi et al., 2010; Al-Kenani, 2014; Yosef et al., 2014; Bokhari et al., 2017; Saad et al., 2017). They declared that the variations in incidence of mycotoxins estimated in raw milk may be related to different reasons such as kind of milk, geographical region, the country, environmental factors (grain drying rate, humidity and temperature) and the analytical procedures applied. According to results collected, incidence and contamination levels of AFM1 in camel's milk, appears to be a severe hazard for public health. As a result, milk from desert animals must be tested and monitored for AFM1 contamination on a regular basis, storage should be strictly monitored, animal meals should be checked for AFB1 on a regular basis, kept at refrigeration temperature and good hygiene practice to prevent contamination with mycotoxins and mold spoilage, acceptable agricultural practices at all stages of the food chain (Yosef et al., 2014). Furthermore, adequate storage conditions may impact the vulnerability of products to fungal attacks at all stages of storage, and processing. As a result, the frequency of contamination in a given product might vary dramatically from region to region and year to year (Tale Hel Abad et al., 2016). Based on the results of this study, the level of Ochratoxin A presence in $17 \%$ of the examined raw milk samples with mean concentrations of 1.69 $\mu \mathrm{g} / \mathrm{l}$. These findings are consistent with the result of other investigators. (Boudra et al., 2007; Elzupir et al., 2009; Tale Hel Abad et al., 2016). They declared that raw milk consumption is one of the OTA's input sources.

Usually, raw milk is marketed without or with a limited traditional heat treatment in most developing countries, including Egypt, which does not alter mycotoxins or their metabolites because they are heatresistant. Because there is a scarcity of data on the natural occurrence of aflatoxins, as well as other factors including a lack of laboratory testing equipment, the authorities have yet to formulate an official rule. It's also worth remembering that Intake of aflatoxin and other mycotoxins from other sources on a daily basis could be a substantial risk factor. (Abdallah et al., 2019).

The level of AFM1 and OTA reported appears to be harmful, based on the facts presented in this research. In reality, assuming a daily raw milk consumption of 200 and $300 \mathrm{ml}$ for adults and children, respectively, (data referred to Egypt - Cairo Nutrition Institute, 1996; 2007), The estimated mycotoxins in the EDI levels for infants and adults were clearly far higher than the recommended daily intake by Kuiper-Goodman (1990); JECFA (2007). Because aflatoxin is considered to be the current most toxic known mycotoxin, its ADI should be absent or the lowest possible. As a result, it is advised that the "ALARA" (As Low As Reasonably Achievable) method be used to assure food safety (Brera et al., 2008). El-Badry (2016) and Milićević et al. (2017) indicated that the majority of raw milk samples tested from various sites in Egypt and Serbia contained mycotoxins in excess of the ADI specified by Global Standards Agencies. Former international researchers, in contrast to the obtained findings, determined that collected milk samples contained levels of mycotoxins that were acceptable for human consumption when compared to suggested 
limits (Pattono et al., 2011; dos Santos et al., 2016).

Fungi in drinking water have gained a lot of attention in recent decades, and they are now widely considered to be contaminants in drinking water. From a limited knowledge basis, information regarding the prevalence and variety of fungus in water has grown significantly (Hageskal et al., 2009). Several investigations have resulted in greater understanding about the presence of fungus in drinking water throughout the previous decade. The presence of potentially dangerous organisms in drinking water, such as Aspergillus fumigatus, has provoked debate about whether water sources may act as a transmission pathway for fungal diseases. Several researches have been done to investigate the occurrence of fungus in water systems (Anaissie et al., 2001; Anaissie et al., 2002; Arvanitidou et al., 2000; Hageskal et al., 2007; Hageskal et al., 2009; Hapcioglu et al., 2005; Kanzler et al., 2007; Warris et al., 2003). Enormous numbers of fungal species have been isolated from nearly every type of water including surface water and ground water either from raw water or/treated water. Furthermore, many studies reported fungal contamination in various types of water from heavily polluted water to distilled or even ultra-pure water (Cabral and Fernandez, 2002; Fujikawa et al., 1997). Some broad findings from all of the investigations are as follows, the recovery of fungi from various water types were varied between 7.5-89 percent positive samples, and the levels of fungi in the samples varied significantly in among various research methodology. According to statistics, Surface-sourced water is three times more likely to contain fungi than ground-sourced water, and Cold water and shower water are more likely to contain fungus than hot tap water. (Hageskal et al., 2007).

Drinking water has been found to be a reservoir for variety of mold species. Species that are possibly pathogenic, allergic, or mycotoxigenic are among them. Aspergillus fumigatus was found in $49 \%$ of the taps water tested in Oslo, Norway (Warris et al., 2001).

Patients with invasive aspergillosis were found to have been infected through the air, water, or both. Furthermore, genetic similarities between isolates from patients and isolates from water settings within the hospital suggested that water was the source of Fusarium infections in Texas, USA. (Warris et al., 2003; Anaissie et al., 2001).

Inhalation of airborne spores is the primary cause of Aspergillosis infections (Annaisie et al., 2002). Water, on the other hand, is becoming more well recognized as a source of Aspergillus spp. in the environment, as well as a source of exposure. The genotypes of A. fumigatus isolates from three individuals were linked to A. fumigatus obtained from water (Warris et al., 2003).

Because pathogenic species, such as Aspergillus spp., have been isolated from drinking water, there is a chance that patients will be exposed to fungi by drinking water. Following genotyping of isolates from the patient and the environment, water has been verified as the source of fungi in a small percentage of instances. Monitoring fungus in drinking water and linking it to an alarm system for fungal infection outbreaks could be used to pinpoint the source of infection in the environment. Ingestion of contaminated water, inhalation of spores that have become aerosolized from running the shower or tap, or use of saunas, skin contact with fungi in water, or introduction via wounds or the conjunctiva when bathing or showering are all possible ways to become infected with fungus through drinking water. There is a significant knowledge gap between the maximum amount of fungus allowed in water and the infection or allergic reaction threshold level. (Hageskal et al., 2007). 
Mycotoxins are produced during the biological life cycle of various fungal species, like Aspergillus spp., Fusariam spp., and Penicillium spp. Those fungal genera were reported to be isolated from water and the most important mycotoxins are aflatoxins and zearalenone, both of which have been detected in drinking water (Paterson and Lima, 2005; Paterson et al., 2009).

It was shown that aflatoxins generated by A. flavus may be detected in water from a cold water storage tank. Because mycotoxins formed in water are substantially diluted, they are likely to be of minor significance. Water is often held for lengthy periods of time in cisterns or reservoirs, or even in bottles. The quantities of mycotoxins may rise in such circumstances. Everyday consumption of large volumes of water, as well as daily ingestion of even low levels of mycotoxins over many years, may be harmful to human health (Paterson et al., 1997; Paterson, 2006).

Because mycotoxins are diluted in drinking water, their concentrations are likely to be quite low (Hageskal et al., 2009; Gonçalves et al., 2006). Kinsey et al. (2003) found only trace quantities of aflatoxins, while Russell and Paterson (2007) found the amount of zearalenone produced in water inoculated with $F$. graminearum to be lower than the dietary concentration. Stored water, such as bottled water, and procedures that evaporate water, such as in various food processing processes, may provide a greater risk as mycotoxins get more concentrated (Gonçalves et al., 2006; Paterson et al., 2009; Paterson and Lima, 2005).

The carcinogenic properties of aflatoxins drive us to create a sensitive, quick, and precise method for identifying and detecting aflatoxin-producing A. flavus in food samples. The aflatoxin biosynthesis genes and their ability to create aflatoxin B1: the structural genes aflD (nor-1) and
aflQ (ordA) found in populations; can be valuable for determining toxicological risk and biocontrol agent selection., as well as forming the basis for a precise, sensitive, and targeted detection system for aflatoxigenic strains of $A$. flavus in foods, using PCR, (Gallo et al., 2012). In this study, using primer designed to aflD (nor-1) and $a f l Q$ (ordA) genes, when compared to traditional plating approaches, the presence of aflatoxigenic A. flavus was easily detected. The PCR methodologies described in this work could be useful in food safety and quality procedures in the future. The obtained findings are consistent with those of Gallo et al. (2012); Hashim et al. (2013) and ELbagory et al. (2014), who found that PCR detection of aflatoxigenic A. flavus from food did not provide any false priming results due to the presence of food or other contaminants. In addition, this methodology allows for the screening of numerous suspicious samples with high sensitivity and accuracy, as well as the capacity to process a large number of samples in a short period of time while conserving resources in fine and expensive food products.

Because variations in fungal sensitivity have been identified for the primary sanitizers used by the food industry, recent research have demonstrated that knowledge of spoilage fungus species of food items in a sector is essential when choosing possible sanitizers (Bernardi et al., 2019).

The antifungal scale established by Bernardi et al. (2018) is used to assess the antifungal effectiveness of the tested sanitizers. All disinfectant showed good to excellent efficacy according the guide line efficacy scale against both $A$. flavus and $A$. ochraceus with minor $\log$ reductions variations when used at the recommended concentrations on pre-cleaned surfaces.

In this investigation, the most effective sanitizer against the fungus species examined under clean conditions was a quaternary ammonium/glutaraldehyde- 
based disinfectant. Instead, variable fungal reduction results, both in relation to species, contact times and, and conditions when Sodium hypochlorite, and Multiple chlorophenolic disinfectants used.

The presence of variances in the sensitivity amongst the species and the same species has thus been proven, so it is advised that the endemic fungus in each dairy sector is isolated and in vitro evaluated for available sanitizers. Sodium hypochlorite showed reduced efficacy against $A$. ochraceus with $1.9 \log$ reduction and its efficacy against $A$. flavus seem to be lower with $1.5 \mathrm{log}$ reduction in the presence of organic contaminates upon exposure time of 5 minutes. A minimum of 30 minutes' contact time was required to yield good efficacy against both $A$. flavus and $A$. ochraceus with 4.2 and $4.3 \log$ reduction, respectively. At the recommended concentration of $50 \mathrm{ppm}$, using any contact times less than half an hour revealed reduced efficacy of Sodium hypochlorite against both $A$. flavus and A. ochraceus. The results obtained for the assessment of sodium hypochlorite sensitivities against fungal species may be widely compared with other literature publications. Use several methods, such dilution tests and various exposure times, sodium hypochlorite inhibited Aspergillus niger at $0.2 \%$ concentration (Ozyurt, 2000). Furthermore, after 5 minutes of exposure to this disinfectant at a concentration of $2.4 \%$, a decrease of more than $5 \log$ of Penicillium, Cladosporium, Mucor, Rhizopus, Alternaria, and Aspergillus was obtained (Reynolds et al., 2004). The presence of organic material in food processing settings is a fact, and this might impact the antifungal disinfectants efficacy. Chlorine exhibits action even at low temperatures, is inexpensive, and has residual effects on surfaces. As a result, it is one of the most commonly utilized compounds in sanitization procedures, and it is regarded as one of the suitable disinfectants for the food industry (Bernardi et al., 2018).
On contaminated dairy surfaces; exposure of A. flavus to Quaternary ammonium/ glutaraldehyde based disinfectant for shorter contact times less than one-hour exhibited reduced efficacy with $\log$ reduction not exceed than $2.6 \mathrm{log}$ while for A. ochraceus, a minimum of 15 minutes' exposure time was required to induce good efficacy with $3.2 \mathrm{log}$ reduction. Adjusting Exposures time for one hour showed good efficacy for both A. flavus and A. ochraceus with 4.5 and $4.6 \log$ reduction, respectively.

Chlorophenolic disinfectants showed the lowest $\log$ reduction and the weaken efficacy against $A$. flavus when used for shorter contact time less than one-hour exposure in dirty dairy environment while it exhibited better performance against $A$. ochraceus that required only exposure time of 15 minutes to result in good efficacy with $3.3 \log$ reduction.

According to some researchers (Lorin et al., 2017; Bernardi et al., 2018), in the presence of milk contaminations, chlorophenolic disinfection and sodium hypochlorite were ineffective in routinely used concentrations and should not be employed when the primary objective of the dairy sector is fungal control. Because of the considerable variability of susceptibility to disinfectants between species and within the same species, in vitro examination of the sensitivities of indigenous fungus of each dairy sector to the available sanitizers is recommended. Contact time was found to be important variable determining the efficacy of the disinfectants in relation to other factors. It was clearly noticed that increasing the exposure time between the fungi and disinfectants lead to good improving of the fungicidal efficacy of all tested biocides used under clean surface conditions. However, using those agents for disinfection of dirty dairy environment still showed reduced efficacy even after elongation of exposure time. Hence, this highlighted the necessity of cleaning and sanitation process for surface cleaning before application of disinfection. It's 
critical to highlight the relevance of industrial environmental sanitization in preventing fungal progeny from being lodged in food and deteriorating it earlier. In industries where Aspergillus sp. is the problem, synergistic formulations contain quaternary ammonium/ glutaraldehyde based disinfectant is good option, achieving good efficacy specially when used after thoroughly cleaning and removal of the organic load. This finding emphasizes the necessity of conducting customized assessments of the disinfectants" effectiveness against the target fungus species found in each food sector (Bernardi et al., 2018). This viewpoint is consistent with previous research, which emphasized the significance of assessing hazardous microorganisms individually, rather than just standard strains, for this sort of test, in order to provide the industry with more cohesive decontamination methods (Lorin et al., 2017).

Mold and yeast anti-biocidal resistance is highly dependent on the isolated strains and species, as well as the disinfectant's active ingredient. Various populations of the same species may react differently to the same disinfectant, resulting in a complete destruction in some cases and no impact in others. To achieve adequate factory hygiene, it is necessary to understand the resistance pattern of spoilage fungi in the process place and product, as well as to pick appropriate disinfectants based on this available data. A single disinfectant is typically insufficient. To keep mold and yeast contamination under control and avoid selection of super resistant isolates, establish a disinfection strategy in which at least two different disinfectants having distinct active components are employed in rotation throughout the production cycle (Bungaard-Nielsen and Nielsen., 1995).

Visible fungal mycelium formation can occur during storage in a retail store or even at the consumer's house, before the shelflife expires (Dagnas and Membré, 2013). In our study, A. flavus growth inhibition was observed at early stage of incubation with various level from $7.33 \mathrm{~mm}$ and $3.21 \mathrm{~mm}$ using quaternary ammonium/ glutaraldehyde and Sodium hypochlorite at the commercial redounded concentrations. Sodium hypochlorite, regardless of the concentration used, marked reduction of mycelium growth inhibitory effect during incubation period was observed. After two weeks, it has very poor inhibitory activities against A. flavus mycelium formation. However, quaternary ammonium/ glutaraldehyde showed consistent good efficacy for inhibition of $A$. flavus mycelial growth, throughout 15-day incubation period (Fig. 3A and B).

Because to AFM1's high toxicity, carcinogenicity, stability, and frequent contamination in milk, many detoxification methods have been developed, including (physical, chemical, and biological); to inactivate or reduce the toxicity of mycotoxins without making substantial modifications to the manufacturing process, in order to avoid human toxicity and maintain the nutritional value of milk (Devreese et al., 2013; Karlovsky et al., 2016). The biological method for mycotoxin detoxification includes using microorganisms especially LAB strains belonging to Streptococcus and Lactobacillus spp. These bacteria are probiotics strains, safe, cost-effective and able to detoxify aflatoxins in milk or dairy products at the different stages of processing through binding of mycotoxins to cell wall peptidoglycans, teichoic acid, polysaccharides, and mycotoxins biodegradation to prevent its adsorption inside human intestine (Chlebicz and Śliżewska, 2020).

In this article, in vivo results demonstrated the ability of mixed starter culture of Streptococcus and Lactobacillus spp. in milk fermentation to reduce the concentration of AFM1. The AFM1 concentration in prepared yoghurt from camel milk was reduced by the tested bacterial strains to varying degrees, on 
average reduction $24.6 \%$ after the first 5 days of incubation, and after 15 and 20 days of incubation, further reduction 45.9 and $55.7 \%$ was observed, respectively. The current observations are generally consistent with previous reports that stated that LAB, particularly Lactobacillus spp., accomplished a wide range of aflatoxins detoxification levels. In these studies, aflatoxin was bound by the tested bacterial strains in the range of $14-49 \%, 20.88$ $59.44 \%$ and $0-85 \%$, respectively (Hernandez-Mendoza et al., 2009; Huang et al., 2017; Kumar et al., 2018). On the basis of the studies conducted, Tajalli et al. (2014) declared that more than $92 \%$ of AFM1 was detoxified by Lactobacillus rhamnosus. Elgerbi et al. (2006) reported that $73.1 \%$ of AFM1 was bounded after 96 $\mathrm{h}$ of incubation by strains of Lactobacillus, Lactococcus and Bifidobacterium spp. The variability in cell wall composition, particularly the concentration of teichoic acid and peptidoglycan, could explain the heterogeneity of Lactobacillus spp ability 's to bind aflatoxin. (Hernandez-Mendoza et al., 2009). LAB also have many advantages to decrease the toxic effect of aflatoxins including anti-carcinogenic activity, antibacterial activity against gastrointestinal pathogens, immunomodulator, maintain normal intestinal flora, protecting lipids, DNA and proteins form oxidative damages (Silva et al., 2015).

\section{CONCLUSION}

Pastoralists in Africa, Middle East and in many arid and semi-arid parts of the world are still depend on camel milk which constitutes an imperative element of their diets. However, camel's milk is now commercially produced and sold. It has recently gained attention as a healthy food in some developed countries globally. The examined raw camel's milk and water samples are contaminated with broad fungal diversity and heterogeneous mycotoxins mixtures including AFB1, AFM1 and OTA. The EDI level of estimated mycotoxins for human obviously were much more than the proposed acceptable daily intake which poses serious public health hazards. The obtained data allowed us to declare the potential of Streptococcus and Lactobacillus spp. to lower and detoxify the AFM1 concentration in prepared yoghurt, giving a potential to be used as detoxifying tool in food and feed additives. The antifungal activity of the disinfectants, the concentration, and the susceptibility of the isolates utilized in the test under clean/dirty conditions exhibited marked variations. Because variations in fungal sensitivity have been identified for the most of sanitizers used by the dairy sector, evaluating the susceptibility of the common spoilage fungus species of dairy products is important when choosing possible antifungal biocides.

\section{REFERENCES}

A.P.H.A. "American Public Health Association" (2004): Standards Methods for Examination of Dairy Products. 17th Ed., American Public Health Association, Washington DC, USA.

Abdallah, M.F.; Girgin, G. and Baydar, T. (2019): Mycotoxin Detection in Maize, Commercial Feed, and Raw Dairy Milk Samples from Assiut City, Egypt. Vet. Sci, 6 (2), 57.

Adams, M.S. and Moss, M.C. (2000): Food Microbiology 2nd. Thomas Graham house, Science Park.

Ahmed, A.E.; AL-Kahtani, M.M.; El-Diasty, E.M.; Ahmed, A.S.; Saber, H.; Abbas, A.M.; Diab, H.M.; Alshehri, M.A.; Elmansi, A.A. and Hussein, M.A. (2020): Diversity of Toxigenic Molds and Mycotoxins Isolated from Dairy Products: Antifungal Activity of Egyptian Marine Algae on Aspergillus and Candida Species. J. Pure Appl. Microbiol, 14(1): 215-232.

Aiad, A.S. and Abo El-Makarem, H.S. (2013): Aflatoxin M1 Levels in Milk and Some Dairy Products in Alexandria City. Assiut Vet. Med. J, 59 (139), 93. 
Aiko, V. and Mehta, A. (2015): Occurrence, Detection and Detoxification of Mycotoxins. J. Biosci, 40 (5), 943-954.

Al-Kenani, A.A. (2014): Detection of Aflatoxin M1 in Camel Milk in Jeddah Province. Master Thesis. King Abdulaziz University: Saudi Arabia.

Amer, A.A. and Ibrahim, M.E. (2010): Determination of Aflatoxin M1 in Raw Milk and Traditional Cheeses Retailed in Egyptian Markets. Journal of Toxicology and Environmental Health Sciences, 2 (4), 50-52.

Anaissie, E.J.; Kuchar, R.T. and Rex, J.H. (2001): Fusariosis Associated with Pathogenic Fusarium Species Colonisation of a Hospital Water System: A New Paradigm for the Epidemiology of Opportunistic Mold Infections. Clinical Infectious Diseases, 33, 1871-1877.

Anaissie, E.J.; Stratton, S.L.; Dignani, M.C.; Summerbell, R.C.; Rex, J.H.; Monson, T.P.; Spencer, T.; Kasai, M.; Francesconi, A. and Walsh, T.J. (2002): Pathogenic Aspergillus Species Recovered from a Hospital Water System: A 3-Year Prospective Study. Clin. Infect. Dis, 34 (6), 780-789.

$A n O, \quad E . ; \quad Z a, \quad M$. and Am, E. (2009): Determination of Aflatoxins and Ochratoxin A in Dairy Cattle Feed and Milk in Wad Medani. Sudan Journal of Animal and Veterinary Advances, 8 (12), 2508-2511.

Armando, M.R.; Pizzolitto, R.P.; Dogi, C.A.; Cristofolini, A.; Merkis, C.; Poloni, V.; Dalcero, A.M. and Cavaglieri, L.R. (2012): Adsorption of Ochratoxin A and Zearalenone by Potential Probiotic Saccharomyces Cerevisiae Strains and Its Relation with Cell Wall Thickness: Ochratoxin A and Zearalenone Adsorption by Yeasts. J. Appl. Microbiol, 113 (2), 256-264.

Arvanitidou, M.; Spaia, S.; Velegraki, A.; Pazarloglou, M.; Kanetidis, D.; Pangidis, P.; Askepidis, N.; Katsinas, C.; Vayonas, G. and Katsouyannopoulos, V. (2000): High Level of Recovery of Fungi from Water and Dialysate in Haemodialysis Units. J. Hosp. Infect, 45 (3), 225-230.
Awad, E.I.; Abdelfattah, M.E.; Abdelkaliek, A.A. and El-diasty, E.M. (2012): Prevalence of Ochratoxin in Small and Large Scale Produced Roomy Cheese in Sharkia Governorate. World Rural Observations, 4.

Barrois, M.T.; Medina, L.M.; Cordoba, M.G. and Jordano, R. (1997): Aflatoxin Producing Strains of Asperigillus Flavus Isolated from Cheese. J. Food Prot, 60, 192-194.

Benkerroum, N.; Boughdadi, A.; Bennani, N. and Hidane, K. (2003): Microbiological quality assessment of Moroccan camel's milk and identification of predominating lactic acid bacteria. World Journal of Microbiology and Biotechnology, 19(6): 645-648.

Bernardi, A.O.; Stefanello, A.; Garcia, M.V.; Parussolo, G.; Stefanello, R.F.; Moro, C.B. and Copetti, M.V. (2018): Efficacy of Commercial Sanitizers against Fungi of Concern in the Food Industry. Lebenson. Wiss. Technol, 97, 25-30.

Bernardi, A.O.; Stefanello, A.; Lemos, J.G.; Garcia, M.V. and Copetti, M.V. (2019): Antifungal Activity of Commercial Sanitizers against Strains of Penicillium Roqueforti, Penicillium Paneum, Hyphopichia Burtonii, and Aspergillus Pseudoglaucus: Bakery Spoilage Fungi. Food Microbiol, 83, 59-63.

Bhat, Z.F. and Bhat, H. (2010): Milk and Dairy Products as Functional Foods: A Review. Int. J. Dairy Sci, 6 (1), 1-12.

Bokhari, F.; Aly, M.; Kelany, A.A. and Rabah, S. (2017): Presence of Aflatoxin M1 in Milk Samples Collected from Jeddah, Saudi Arabia. IOSR J. Pharm, 07 (05), 49-52.

Boudra, H.; Barnouin, J.; Dragacci, S. and Morgavi, D.P. (2007): Aflatoxin M1 and Ochratoxin A in Raw Bulk Milk from French Dairy Herds. J. Dairy Sci, 90 (7), 3197-3201.

Brera, C.; De Santis, B.; Debegnach, F. and Miraglia, M. (2008): Chapter 12: Mycotoxins; Yolanda, P., Ed.; Elsevier Applied Science: Amesterdam, Netherlands, Vol. 51, pp 363-427. 
Bundgaard-Nielsen, $K$. and Nielsen, P.V. (1996): Fungicidal Effect of 15 Disinfectants against 25 Fungal Contaminants Commonly Found in Bread and Cheese Manufacturing. J. Food Prot, 59 (3), 268-275.

Cabral, D. and Fernández Pinto, V.E. (2002): Fungal Spoilage of Bottled Mineral Water. Int. J. Food Microbiol, 72 (1-2), 73-76.

Cary, J.W.; Klich, M.A. and Beltz, S.B. (2005): Characterization Aflatoxin Producing Fungi Outside of Aspergillus Section Flavi. Mycologia, 97, 425-432.

Chlebicz, A. and Śliżewska, K. (2020): In Vitro Detoxification of Aflatoxin B1, Deoxynivalenol, Fumonisins, T-2 Toxin and Zearalenone by Probiotic Bacteria from Genus Lactobacillus and Saccharomyces Cerevisiae Yeast. Probiotics Antimicrob. Proteins, 12 (1), 289-301.

Clark, H.A. and Snedeker, S.M. (2006): Ochratoxin A: Its Cancer Risk and Potential for Exposure. J. Toxicol. Environ. Health B Crit. Rev, 9 (3), 265-296.

Coffey, R.; Cummins, E. and Ward, S. (2009): Exposure Assessment of Mycotoxins in Dairy Milk. Food Control, 20 (3), 239249.

Colak, H. (2020): Determination of Aflatoxin M1 Levels in Turkish White and Kashar Cheeses Made of Experimentally Contaminated Raw Milk. J. Food Drug Anal, 15 (2). https://doi.org/10.38212/22246614.2428

da Silva, J.F.M.; Peluzio, J.M.; Prado, G.; Madeira, J.E.G.C.; Silva, M.O.; de Morais, P.B.; Rosa, C.A.; Pimenta, R.S. and Nicoli, J.R. (2015): Use of Probiotics to Control Aflatoxin Production in Peanut Grains. Scientific World Journal, 959138.

Dagnas, S. and Membré, J.-M. (2013): Predicting and Preventing Mold Spoilage of Food Products. J. Food Prot, 76 (3), 538-551.

Daily consumption of adult person in Egypt, No. $\quad 43906 . \quad$ (2007): $\quad$ http:// www.elharm.com/ 9134/INVES.HTM.
Devreese, M.; De Backer, P. and Croubels, S. (2013): Different Methods to Counteract Mycotoxin Production and Its Impact on Animal Health. Vlaams Diergeneeskd., 82 (4), 181-190.

Diab, H.M.; Alkahtani, M.A.; Ahmed, A.S.; Khalil, A.M.; Alshehri, M.A.; Ahmed, M.A.A.; Rehan, I.F.; Elmansi, A.A. and Ahmed, A.E. (2020): Coexistence of Diverse Heavy Metal Pollution Magnitudes: Health Risk Assessment of Affected Cattle and Human Population in Some Rural Regions, Qena, Egypt. J. Adv. Vet. Anim. Res, 7 (2), 345-359.

Doyle, M.P.; Beuchat, L.R. and Montuille, T.J. (1997): Mycotoxigenic Molds, Food Microbiology; Asm. Press: USA.

Drusch, S. and Aumann, J. (2005): Mycotoxins in Fruits: Microbiology, Occurrence, and Changes during Fruit Processing. Adv. Food Nutr. Res, 50, 33-78.

Eddine, S.D.; Yasmine, S.; Fatima, G.; Amina, Z.; Battache, G. and Mebrouk, K. (2021): Antifungal and Antibacterial Activity of Some Lactobacilli Isolated from Camel's Milk Biotope in the South of Algeria. Journal of Microbiology, Biotechnology and Food Sciences, 871-877.

Egyptian Organization for Standardization and Quality Control (EOSQC) (2005): "1008/2005", "1185-1/2005", "1414/2005". Egyptian Organization for Standardization and Quality Control. Egyptian Standards (E.S.) No.: 1008/2005, 1185-1/2005, 1414/2005.

El-Badry, S. (2016): Determination of Ochratoxin A Residues in Some Animal and Plant Milk Products. Zagazig Vet. J, 44 (2), 101-105.

ELbagory, A.M.; Eid, A.M.; Hammad, A.M. and Dawood, S.A. (2014): Prevalence of Fungi in Locally Produced Cheese and Molecular Characterization of Isolated Toxigenic Molds. Benha Veterinary Medical Journal, 27 (2), 920.

Elgerbi, A.M.; Aidoo, K.E.; Candlish, A.A.G. and Williams, A.G. (2006): Effects of Lactic Acid Bacteria and Bifidobacteria 
on Levels of Aflatoxin M1 in Milk and Phosphate Buffer. Milchwissenschaft, 61, 197-199.

El-Nezami, H.; Kankaanpaa, P.; Salminen, S. and Ahokas, J. (1998): Ability of Dairy Strains of Lactic Acid Bacteria to Bind a Common Food Carcinogen, Aflatoxin B1. Food Chem. Toxicol. 36 (4), 321326.

El-Ziney, M.G. and Al-Turki, A.I. (2007): Microbiological quality and safety assessment of camel milk (Camelus dromedaries) in Saudi Arabia (Qassim region). Applied Ecology and Environmental Research, 5(2): 115122.

Espigares, E.; Bueno, A.; FernándezCrehuet, M. and Espigares, M. (2003):

Efficacy of Some Neutralizers in Suspension Tests Determining the Activity of Disinfectants. J. Hosp. Infect, 55 (2), 137-140.

European Commission Regulation (EC), (2006): No 1881/2006 of 19 December 2006 setting maximum levels for certain contaminants in foodstuffs. Official Journal of European Union, 364:5-24.

European Standard chemical disinfectants. EN 1657:2005/AC: 2007 (2007): Chemical disinfectants and antiseptics Quantitative suspension test for the evaluation of fungicidal or yeasticidal activity of chemical disinfectants and antiseptics used in the veterinary area Test method and requirements (phase 2, step 1).

FAO "Food and Agriculture Organization" (1992): Manual of food quality control.

4. Rev. 1. Microbiological analysis. Food and Agriculture Organization of the United Nations, Rome, Italy.

FAO /WHO. Guidelines for the Evaluation of Probiotics in Food. (2002): Report of a Joint FAO/WHO Working Group on Drafting Guidelines for the Evaluation of Probiotics in Food; London Ontario, Canada.

Foster, E.M.; Nelson, F.E.; Speck, M.L.; Doetsch, R.N. and Olson Jr, J.C. (1983): Dairy Microbiology. Dairy Microbiology. Macmillan Colt., London.
Frisvad, J.C.; Skouboe, P. and Samson, R.A. (2005): Taxonomic Comparison of Three Different Groups of Aflatoxin Producers and a New Efficient Producer of Aflatoxin B1, Sterigmatocystin and 3Omethylsterigmatocystin, Aspergillus Rambellii Sp. Nov. Systematic and Applied Microbiology 2005, 28, 442453.

Fujikawa, H.; Wauke, T.; Kusunoki, J.; Noguchi, Y.; Takahashi, Y.; Ohta, K. and Itoh, T. (1997): Contamination of Microbial Foreign Bodies in Bottled Mineral Water in Tokyo, Japan. J. Appl. Microbiol, 82 (3), 287-291.

Galeboe, O.; Seifu, E. and Sekwati-Monang, B. (2018): Production of Camel Milk Yoghurt: Physicochemical and Microbiological Quality and Consumer Acceptability. Int. J. Food Stud, 7 (2). https://doi.org/10.7455/ijfs.v7i2.473.

Gallo, A.; Stea, G.; Battilani, P.; Logrieco, A.F. and Perrone, G. (2012): Molecular Characterization of an Aspergillus Flavus Population Isolated from Maize during the First Outbreak of Aflatoxin Contamination in Italy. Phytopatho. Mediterr, 51, 198-206.

Gemeda, N.; Woldeamanuel, Y.; Asrat, D.; Debela, A.; Lemma, H. and Belete, $Y$. (2014): Assessment of aflatoxigenic Aspergillus species in food commodities from local market of Addis Ababa. Research, 1: 1195.

Gonçalves, A.B.; Paterson, R.R.M. and Lima, N. (2006): Survey and Significance of Filamentous Fungi from Tap Water. Int. J. Hyg. Environ. Health, 209 (3), 257-264.

González-Salgado, A.; Patiño, B.; Vázquez, C. and González-Jaén, M.T. (2005): Discrimination of Aspergillus Niger and Other Aspergillus Species Belonging to Section Nigri by PCR Assays. FEMS Microbiol. Lett, 245 (2), 353-361.

Guide of Healthy Food for Egyptian Family, 2nd ed. (1996): Nutrition Institute, Cairo, Egypt.

Hageskal, G.; Gaustad, P.; Heier, B.T. and Skaar, I. (2007): Occurrence of Molds 
in Drinking Water. Journal of Applied Microbiology, 102 (3), 774-780.

Hageskal, G.; Lima, N. and Skaar, I. (2009): The Study of Fungi in Drinking Water. Mycol. Res, 113 (Pt 2), 165-172.

Hapcioglu, B.; Yegenoglu, Y.; Erturan, Z.; Nakipoglu, Y. and Issever, H. (2005): Heterotrophic Bacteria and Filamentous Fungi Isolated from a Hospital Water Distribution System. Indoor Built Environ, 14 (6), 487-493.

Harrigan, W.F. and MacCance Margaret, E. (1996): Laboratory Methods in Microbiology; Academic Press: New York, USA.

Hashim, A.J.; Al-Kazaz, A.A. and Abdalmalek, W.H. (2013): PCR Detection of Aspergillus Flavus Isolates for Aflatoxin B1 Producer. J. of Biotechnology Research Center, 7 (3), 81-89.

Hernandez, A.; Martro, E.; Matas, L.; Martin, M. and Ausina, V. (2000): Assessment of In-Vitro Efficacy of 1\% Virkon against Bacteria, Fungi, Viruses and Spores by Means of AFNOR Guidelines. J. Hosp. Inf, 46, 203-209.

Hernandez-Mendoza, A.; Garcia, H.S. and Steele, J.L. (2009): Screening of Lactobacillus Casei Strains for Their Ability to Bind Aflatoxin B1. Food Chem. Toxicol, 47 (6), 1064-1068.

Hocking, A.D. (2006): Aspergillus and Related Teleomorphs. In Food Spoilage Microorganisms; Elsevier; pp 451-487.

Huang, L.; Duan, C.; Zhao, Y.; Gao, L.; Niu, C.; $X u, J$. and Li, S. (2017): Reduction of Aflatoxin B1 Toxicity by Lactobacillus Plantarum C88: A Potential Probiotic Strain Isolated from Chinese Traditional Fermented Food "Tofu." PLoS One, 12 (1), e0170109.

I A R C. (2002): Some Traditional Herbal Medicines: Some Mycotoxins, Naphthalene and Styrene; Lyon, France; Vol. 82, pp 1-556.

Ismaili, M.A.; Saidi, B.; Zahar, M.; Hamama, $A$. and Ezzaier, R. (2019): Composition and Microbial Quality of Raw Camel Milk Produced in Morocco. Journal of the Saudi Society of Agricultural Sciences, 18 (1), 17-21.
Ji, C.; Fan, Y. and Zhao, L. (2016): Review on Biological Degradation of Mycotoxins. Anim. Nutr, 2 (3), 127133.

Joint FAO/WHO Expert Committee on Food Additives. (2007): Evaluation of Certain Food Additives and Contaminants. World Health Organ. Tech. Rep. Ser. 2007, No. 940, 1-92, 1 $\mathrm{p}$ following 94 .

Jooyandeh, H.; Mortazavi, A.; Farhang, P. and Samavati, V. (2015): Physicochemical Properties of SetStyle Yoghurt as Effected by Microbial Transglutaminase and Milk Solids Contents. J. Appl. Environ. Biol. Sci, 4, 59-67.

Kaindi, D.W.M.; Schelling, E.; Wangoh, J.; Imungi, J.K.; Farah, Z. and Meile, L. (2011): Microbiological Quality of Raw Camel Milk across the Kenyan Market Chain. Food, 5 (1), 79-83.

Kanzler, D.; Buzina, W.; Paulitsch, A.; Haas, D.; Platzer, S.; Marth, E. and Mascher, F. (2008): Occurrence and Hygienic Relevance of Fungi in Drinking Water. Mycoses, 51 (2), 165-169.

Karlovsky, P.; Suman, M.; Berthiller, F.; De Meester, J.; Eisenbrand, G.; Perrin, I.; Oswald, I. P.; Speijers, G.; Chiodini, A.; Recker, T. and Dussort, P. (2016): Impact of Food Processing and Detoxification Treatments on Mycotoxin Contamination. Mycotoxin Res, 32 (4), 179-205.

Kelley, J.; Paterson, R.; Kinsey, G.; Pitchers, $R$. and Rossmoore, H. (1997): Identification, Significance and Control of Fungi in Water Distribution Systems; US. Public American Water Works Association: Denver, CO.

Kinsey, G.; Paterson, $R$. and Kelley, $J$. (2003): Filamentous Fungi in Water Systems. In Handbook of Water and Wastewater Microbiology; Elsevier; pp 77-98.

Kuiper-Goodman, T. (1990): Uncertainties in the Risk Assessment of Three Mycotoxins: Aflatoxin, Ochratoxin, and Zearalenone. Can. J. Physiol. Pharmacol, 68 (7), 1017-1024.

Kumar, S.S.; Bashisht, A.; Venkateswaran, G.; Hariprasad, P. and Gayathri, D. 
(2018): Characterization of Novel Lactobacillus Fermentum from Curd Samples of Indigenous Cows from Malnad Region, Karnataka, for Their Aflatoxin B1 Binding and Probiotic Properties; Probiotics Antimicrob Proteins, 2018.

Langsrud, S.; Sidhu, M.S.; Heir, E. and Holck, A.L. (2003): Bacterial Disinfectant Resistance-a Challenge for the Food Industry. Int. Biodeterior. Biodegradation, 51 (4), 283-290.

Ledenbach, L.H. and Marshall, R.T. (2010): Microbiological Spoilage of Dairy Products. In Compendium of the Microbiological Spoilage of Food and Beverages. Food safety, 41-67.

Lewis, W.M. and Waddington, J.I. (1981): WHO International Drinking Water Standards Revised. Sci. Total Environ, 18, 285-292.

Lin, L.C.; Liu, F.M.; Fu, Y.M. and Shih, D.Y.C. (2004): Survey of Aflatoxin M Sub (1) Contamination of Dairy Products in Taiwan. Journal of Food and Drug Analysis, 12 (2), 154-160.

Lorin, D.; Cristina, R.T.; Teusda, V.; Mitranescu, E.; Muselin, F. and Butnariu, M. (2017): Efficacy of Four Currently Used Decontamination Conditionings in Romania against Aspergillus and Candida Strains. Journal de Mycologie Médicale, 27, 357-363.

Martins, M.L.; Martins, H.M. and Bernardo, F. (2001): Aflatoxins in Spices Marketed in Portugal. Food Addit. Contam, 18 (4), 315-319.

Milićević, D.; Spirić, D.; Janković, S.; Velebit, B.; Radičević, T.; Petrović, Z. and Stefanović, S. (2017): Aflatoxin M1 in Processed Milk: Occurrence and Seasonal Variation with an Emphasis on Risk Assessment of Human Exposure in Serbia. IOP Conf. Ser. Earth Environ. Sci, 85, 012040.

Mislivec, P.B.; Beuchat, L.R.; Cousin, M.A. Yeasts and Molds. (1992): Chapter 16 Compendium of Methods for Microbiological Examination of Food, 3rd ed.; American Public Health Association: Washington, DC.
Mosallaie, F.; Jooyandeh, H.; Hojjati, M. and Fazlara, A. (2020): Biological Reduction of Aflatoxin B1 in Yogurt by Probiotic Strains of Lactobacillus Acidophilus and Lactobacillus Rhamnosus. Food Sci. Biotechnol, 29 (6), 793-803.

Muir, D.D. and Banks, J.M. (2000): Milk and Milk Products in the Stability and Shelf Life of Food. BocaRaton. FL, 197, 219.

Okoth, S.; De Boevre, M.; Vidal, A.; Diana Di Mavungu, J.; Landschoot, S.; Kyallo, M.; Njuguna, J.; Harvey, J. and De Saeger, S. (2018): Genetic and Toxigenic Variability within Aspergillus Flavus Population Isolated from Maize in Two Diverse Environments in Kenya. Front. Microbiol, 9, 57.

Ozyurt, M. (2000): Methods of disinfection and sterilization. Journal of Clinic Microbiology, 13: 41-48.

Paterson, R.R.M. (2006): Fungi and Fungal Toxins as Weapons. Mycol. Res, 110 (Pt 9), 1003-1010.

Paterson, R.R.M. and Lima, N. (2005): Fungal Contamination of Drinking Water; John Whiley and Sons.

Paterson, R.R.M.; Hageskal, G.; Skaar, I.; Lima, N. (2009): Occurrence, Problems, Analysis and Removal of Filamentous Fungi in Drinking Water; De Costa, P. A. B., P, Eds.; Nova Science Publishers, Inc.

Paterson, R.R.; Kelley, J. and Gallagher, M. (1997): Natural Occurrence of Aflatoxins and Aspergillus Flavus (Link) in Water. Lett. Appl. Microbiol, 25 (6), 435-436.

Pattono, D.; Gallo, P.F. and Civera, T. (2011): Detection and Quantification of Ochratoxin A in Milk Produced in Organic Farms. Food Chem, 127 (1), 374-377.

Pitt, J.I. and Hoching, A.D. Fungi and Food spoilage, 3rd Ed. (2009): Blackie Academic and professional Academic Press, Springer Science, New York, London.

Rahimi, E.; Bonyadian, M.; Rafei, M. and Kazemeini, H.R. (2010): Occurrence of Aflatoxin M1 in Raw Milk of Five 
Dairy Species in Ahvaz, Iran. Food Chem. Toxicol, 48 (1), 129-131.

Reynolds, K. (2004): Efficacy of Sodium Hypochlorite Disinfectant on the Viability and Allergenic Properties of Household Mold*1. J. Allergy Clin. Immunol, 113 (2), S180.

Russell, A.D. (1981): Neutralization Procedures in the Evaluation of Bactericidal Activity; Collins, C.H., Allwood, M.C., Bloomfield, S.F., Fox, A., Eds.; Academic Press: London, 1981.

Russell, R. and Paterson, M. (2007): Zearalenone Production and Growth in Drinking Water Inoculated with Fusarium Graminearum. Mycol. Prog, 6 (2), 109-113.

Rutala, W.A. (1996): APIC Guideline for Selection and Use of Disinfectants. 1994, 1995, and 1996 APIC Guidelines Committee. Association for Professionals in Infection Control and Epidemiology, Inc. Am. J. Infect. Control 1996, 24 (4), 313-342.

Saad, N.; Amin, W.; Zaky, Z. and Blall, L. (2017): Assessment of Aflatoxin M1 in Raw Milk of Some Dairy Animals. Zagazig Veterinary Journal, 9(8): 6671.

Santos, JS.; V, G.; Gm, P.; Lrs, R. and Ih, C. (2016): Aflatoxin M1 in Pasteurized and Raw Milk from Organic and Conventional Systems. Journal für Verbraucherschutz und Lebensmittelsicherheit, 11 (4), 299304.

Seddek, N.H.; Gomah, N.H. and Osman, D.M. (2016): Fungal Flora Contaminating Egyptian Ras Cheese with Reference to Their Toxins and Enzymes. Food Science and Technology, 4 (4), 64-68.

Sengun, I.; Yaman, D. and Gonul, S. (2008): Mycotoxins and Mold Contamination in Cheese. World Mycotox. J 2008, 3, 291-298.

Subrota Hati, D.S. (2018): Fermented Camel Milk: A Review on Its Bio-Functional Properties. Emir. J. Food Agric, 30 (4), 268.

Tajalli, F.; Sarabi Jamab, M.; Adibpour, N.; Mehraban Sang Atash, M. and
Karazhian, R. (2014): Evaluation of Lactobacillus Rhamnosus Viability Effect on Reduction of Aflatoxin M1 in Probiotic Yogurt. BioTechnol. An Indian J, 10, 16486-16491.

Tale Hel Abad, S.; Joshaghani, H.R.; Rahimzadeh, H.; Niknejad, $F$. and Kiaie, M.R. (2016): Ochratoxin A in cow's milk collected from cattle farms of Golestan Province. Medical Laboratory Journal. 10(1): 13-16.

Teniola, O.D.; Addo, P.A.; Brost, I.M.; Farber, P.; Jany, K.D.; Alberts, J.F.; Van Zyl, W.H. and Steyn, P.S. (2005): Degradation of Aflatoxin B1 by CellFree Extracts of Rhodococcus Erythropolis and Mycobacterium Fluoranthenivorans Sp. Nov. DSM44556T. Int $\mathbf{J}$ Food Microbiol, 105, 111-117.

Visconti, A.; Pascale, M. and Centonze, G. (2000): Determination of Ochratoxin A in Domestic and Imported Beers in Italy by Immunoaffinity Clean-up and Liquid Chromatography. J. Chromatogr. A 2000, 888 (1-2), 321326.

Warris, A.; Gaustad, P.; Meis, J.F.; Voss, A.; Verweij, P.E. and Abrahamsen, T.G. (2001): Recovery of Filamentous Fungi from Water in a Paediatric Bone Marrow Transplantation Unit. J. Hosp. Infect, 47 (2), 143-148.

Warris, A.; Klaassen, C.H.W.; Meis, J.F.G.M.; De Ruiter, M.T.; De Valk, H.A.; Abrahamsen, T.G.; Gaustad, P. and Verweij, P.E. (2003): Molecular Epidemiology of Aspergillus Fumigatus Isolates Recovered from Water, Air, and Patients Shows Two Clusters of Genetically Distinct Strains. J. Clin. Microbiol, 41 (9), 4101-4106.

Yosef, T.A.; Al-Julaifi, M.Z.; Hussein, Y.A.; Al-Shokair, S.S. and Al-Amer, A.S. (2014): Occurrence of Aflatoxin M1 in Raw Camel Milk in El-Ahsa Governorate, Saudi Arabia. Nature and science, 12 (4).

Zain, M.E. (2011): Impact of Mycotoxins on Humans and Animals. J. Saudi Chem. Soc, 15 (2), 129-144.

Zakaria, A.M.; Amin, Y.A.; Khalil, O.S.F.; Abdelhiee, E.Y. and Elkamshishi, M.M. 
(2019): Rapid Detection of Aflatoxin M1 Residues in Market Milk in Aswan Province, Egypt and Effect of Probiotics on Its Residues Concentration. J. Adv. Vet. Anim. Res, $6(2), 197-201$.
Zhu, Y.; Hassan, Y.; Lepp, D.; Shao, S. and Zhou, T. (2017): Strategies and Methodologies for Developing Microbial Detoxification Systems to Mitigate Mycotoxins. Toxins (Basel), 9 (4), 130.

\title{
فعالية المطهرات المضادة للفطريات على معزولات الاسبرجلس من حليب الإبل ومياه الثرب:

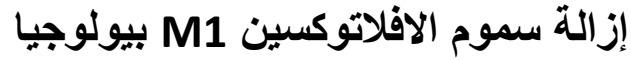

\author{
حسن محمود دياب ، أحدد شعبان أحد ، لؤى الكاظمى ، جابر الصابر بطيحة ، منى أحدد الزرقان
}

Email: ahmed_shaaban@vet.svu.edu.eg Assiut University web-site: www.aun.edu.eg

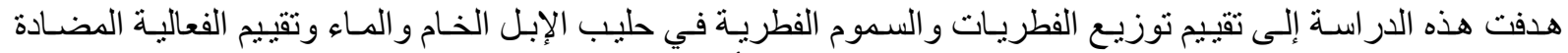

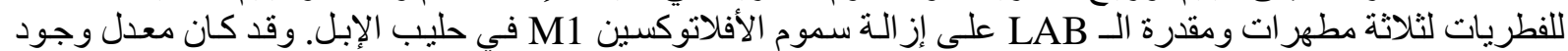

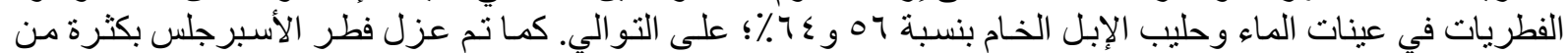

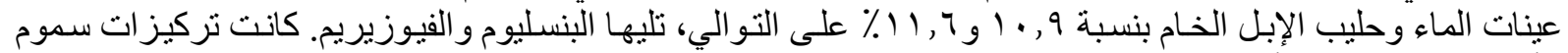

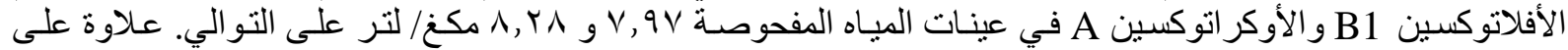

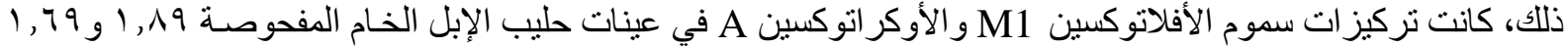

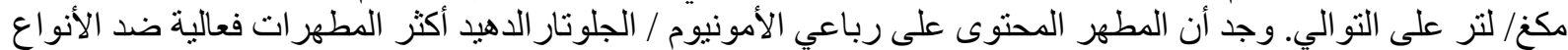

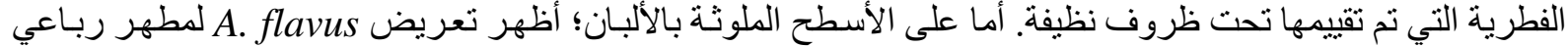

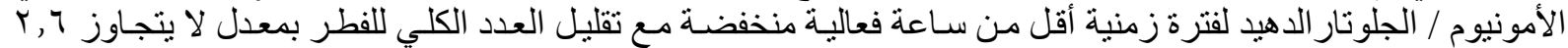

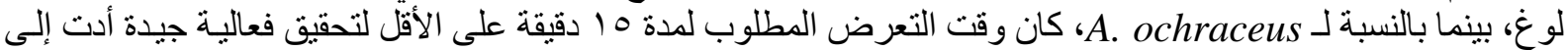

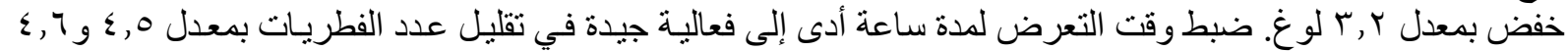

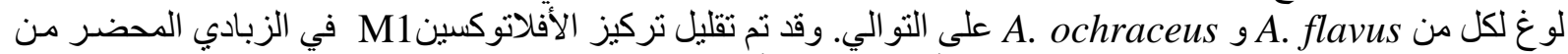

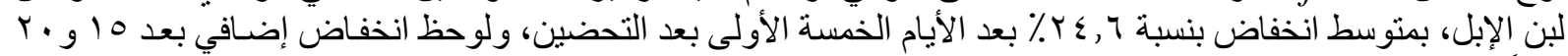

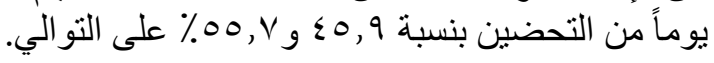

